\title{
Daredevil as Legal Emblem
}

\author{
Timothy D. Peters
}

University of the Sunshine Coast, Australia

\begin{abstract}
This article draws together two trajectories of legal scholarship: the turn to the visual in legal studies and the emergence of the subfield of law and comics, or 'graphic justice'. It does this via an analysis of superhero comics as fitting within a particular genealogy of the ius imaginum, or law of images. This is not to argue simply that superhero comics are dominated by narratives of law, justice and legality - they are - but rather that the very theatrical figure of the superhero and its encompassing of a dual persona is a presentation of a particular political theology of the image. The article analyses the way in which this political theology is rendered visible in Charles Soule's Daredevil: Back in Black, highlighting the image of the superhero and its connection to both sovereignty and the biopolitics of personhood.
\end{abstract}

Keywords: Law of images; legal emblem; Daredevil; law and the visual; graphic justice; law and comic.

"Law exists in a world of images whose power is not located primarily in their representation of something exterior, but instead is found in images themselves."

Sarat, $2000{ }^{1}$

\section{Introduction}

"What authorises the image?" This question was posed by Richard Sherwin in a recent exploration of the jurisprudential concerns related to the emergence of our modern visual economy. ${ }^{2}$ If, as Austin Sarat declared 20 years ago, law lives in the image, what is the authority of the image, its significance and force? ${ }^{3}$ How does this question of authority relate to the superabundance of representations that dominate our contemporary 'post-truth' era that Sherwin names the neo-baroque? ${ }^{4}$ More specifically, what is the significance of the legal image and the representations of law? What distinguishes the figure of Justitia before a courthouse from its representation in film and television, or the architecture, aesthetics and ornament of the courtroom from a graphic representation of a court in session? Our era of the proliferation of images - fictional and factual, realist or abstract, dramatically manipulated yet generating a reality-effect—is one that both calls into question the authority of the image and succumbs to its affect. ${ }^{5}$ These concerns with the nature and authority of the image have infused the recent turn to the visual in legal scholarship and its analysis of the interrelationship between law and art, legality and the image, justice and visuality. ${ }^{6}$ Concurrently, the rise of the subfield of law and comics, or 'graphic justice', has encompassed a critical interrogation of the

\footnotetext{
${ }^{1}$ Sarat, "Imagining the Law of the Father," 8.

2 Sherwin, "What Authorizes the Image."

${ }^{3}$ Sarat, "Imagining the Law of the Father," 39.

${ }^{4}$ Sherwin, Visualising Law; for a discussion of 'post-truth' and 'truthiness', see Crawley, "Confessor."

${ }^{5}$ Sherwin, "Introduction."; Crawley, "Representational Legality."

${ }^{6}$ See, for example: Douzinas, Law and the Image; Sherwin, Visualising Law; Goodrich, Legal Emblems; Wagner, Law, Culture and Visual Studies; Peters, Envisioning Legality; Manderson, Law and the Visual.
}

Except where otherwise noted, content in this journal is licensed under a Creative Commons Attribution 4.0 International Licence. As an open access journal, articles are free to use with proper attribution. ISSN: 2652-4074 (Online) 
legality of the comics image - a lex comicus or, as Thomas Giddens has more recently described it, a komos that mediates the relationship between chaos and law. ${ }^{7}$

This article seeks to draw together these two trajectories of legal scholarship via an analysis of superhero comics as fitting within a particular genealogy of the ius imaginum, or law of images. This is not to argue simply that superhero comics are dominated by narratives of law, justice and legality - they are - but rather that the very theatrical figure of the superhero and its dual persona is a presentation of a particular political theology of the image. Such a political theology and the scholarly concern over the superhero's relationship to sovereignty, ${ }^{8}$ while having roots in earlier understandings of the image and icon, encompass an aspect of what Eric Santner has termed the 'flesh' of the 'royal remains' - the phantasmal presence, the 'sublime' life substance - that in modernity is born by 'the People' and underwrites popular sovereignty. ${ }^{9}$ Central to this modern understanding of 'the People' as bearers of sovereignty is the way in which law draws the human, presenting, as I will demonstrate through a critical reading of Charles Soule's run on the superhero comic Daredevil (Daredevil: Back in Black), the person as an image, an optical apparatus (to borrow Peter Goodrich's term) represented by and to law. ${ }^{10}$

The article proceeds in four parts. Section 2 takes up and sustains my claim that superhero comics fit within the genealogy of the law of images, by analysing the emblematic signifiers of the comic and, in particular, providing an emblematic reading of that famed lawyer-by-day, superhero-by-night, Daredevil. Such a reading is invited by both the superhero duality (masked vigilante Daredevil, lawyer Matt Murdock) and the explicit parallels with that other figure of 'blind justice', Justitia. Section 3 then turns to the recent apogee of such an emblematic rendering in Soule's run on Daredevil, focusing in particular on its preponderance with the question of the superhero's dual identity and its significance for law. Section 4 explores the historic precursors of the emblematic characteristics of the superhero that are presented in Soule's run, in terms of both the political theology of sovereignty and the biopolitical apparatus of personhood. Section 5 then places these specific concerns within a broader consideration of the vision of law and legality that Soule provides, by considering both the visual re-signifying of legal emblems (courtroom, judge, gavel) as well as the inversion of Daredevil's traditional duality - with the lawyer, rather than the superhero, having superpowers in terms of their 'use' of the law. The article concludes, however, with a note of caution. For while Soule, at one level, presents a new legal humanism - concerned with the relation of ethics to law-he does so in terms of a vision of law as a pure instrument of power deployed by the skilled and superpowered lawyer.

\section{Superhero as Legal Emblem: Daredevil and Lady Justice}

This article articulates the law's functioning through images and what I, with Karen Crawley, have referred to as "representational legality" 11 by situating the superhero comic within the tradition of the legal emblem, the mens emblematica, which Peter Goodrich and Valérie Hayaert have reconstructed. ${ }^{12}$ In contributing to the literature on law and comics or graphic justice, I place this field within the longue durée of the ius imaginum, or law of images. While comics studies encompasses disciplinary debates over the definition of comics, their origin and historical development, ${ }^{13}$ the 16 th-century 'emblem book', invented by the lawyer Andrea Alciato, forms a crucial part of the 'pre-history' of the comic. ${ }^{14}$ As Goodrich has noted, the emblem book's status in the history of the law of images is determined not simply in terms of its role in the "pictorial turn in the early history of publishing," but rather the "visiocracy" that it performed. ${ }^{15}$ With its significant (though not exclusive) focus on juridical themes - sovereignty, justice, authority - the emblem book was used by the ecclesiastical and civil lawyers "to make law visible, manifest, and present." 16 This took both governmental and didactic forms. At one level it functioned as "a

\footnotetext{
${ }^{7}$ On 'lex comicus' see Giddens, "Lex Comica," 8-15; for the concern with this term and the broader consideration of 'komos' see Giddens, On Comics and Legal Aesthetics, xiv-xvi; on graphic justice in general, see Giddens, Graphic Justice. See also the 2012 special issue "Justice Framed: Law in Comics and Graphic Novels" in Volume 16 of Law Text Culture: Gómez Romero, "Introduction - Justice Framed."

${ }^{8}$ Most notably, Curtis, "Superheroes and the Contradiction.”; Curtis, Sovereignty and Superheroes. See also Bainbridge, "Spider-Man, The Question and the Meta-Zone."; Bainbridge, "Call to Do Justice.”; Peters, "Beyond the Limits."

${ }^{9}$ Santner, Royal Remains; Kantorowicz, King's Two Bodies; Mondzain, Image, Icon, Economy.

${ }^{10}$ Soule, Daredevil: Back in Black Vol. 1; Soule, Daredevil: Back in Black Vol. 2; Soule, Daredevil: Back in Black Vol. 3; Soule, Daredevil:

Back in Black Vol. 4; Soule, Daredevil: Back in Black Vol. 5; Soule, Daredevil: Back in Black Vol. 6; Soule, Daredevil: Back in Black Vol.

7; Soule, Daredevil: Back in Black Vol. 8; on the 'optical apparatus of the person' see Goodrich, "Theatre of Emblems."

${ }^{11}$ Crawley, "Representational Legality."

${ }^{12}$ Goodrich, Legal Emblems; Hayaert, "Emblems.” See also Hayaert, Mens Emblematica; Goodrich, Genealogies of Legal Vision.

${ }^{13}$ For a consideration of comics studies, including the definitional debates, from a jurisprudential perspective, see Giddens, On Comics and Legal Aesthetics. See also Giddens, Critical Directions.

${ }^{14}$ For an analysis of X-Men comics within the emblem tradition, see Briest, "Allegorical X-Men." See also Grove, Text/Image Mosaics. For Goodrich's own consideration of comics, see Goodrich, "Mask as Anti-Apparatus."

${ }^{15}$ Goodrich, Legal Emblems, xv; Goodrich, "Visiocracy."

${ }^{16}$ Goodrich, Legal Emblems, xv.
} 
form of legislation, a making of the rules, an enactment of the norm" but this "government of images" also encompassed a "licit and visible order that the emblem tradition taught the subject to see and to observe." 17

The history of these forms is not simply of esoteric interest. As Goodrich demonstrates, the images that adorn our courtrooms and legal institutions today are our modern emblems that, in themselves, have remained relatively stable since the beginning of the modern tradition of law and that inform and structure our legal imaginary. ${ }^{18}$ Whether it is the architecture, dress and performance of our courtrooms (the bench, robes and gavel), or the traditional images of justice (the blindfold, sword and scales) and sovereignty (height, power and clouds) that adorn them, our archive of legal images encompass and circulate particular and consistent ocular forms. ${ }^{19}$ In the emerging era of digital legality, these emblems are also reproduced in fictional, factual and iconic forms - continuing and extending beyond their original context and sustaining, even in its transformation, a particular vision of legality. ${ }^{20}$ At the same time, in addition to the governmental and didactic roles of the emblem book-and the legal emblems that we have thus inherited - is the way in which the combination of "image and letter, visual and verbal, theatre and law...played with the boundaries of the norm and unsettled the certainty and ease of the inherited acclamatory ceremonies." 21 That is, as Goodrich notes, "[t]he image made manifest in the text of governance is also a quintessential vehicle of satire and critique of law." 22

My argument here is that the superhero genre, and superhero comics in particular-with their meditations on law and its exception, justice and legality, authority and the heroic - are both inheritors and promulgators of a particularly modern legal imaginary captured by the continuity of our legal emblems, while themselves engaging in the satirical and critical aspects of the emblem tradition. ${ }^{23}$ The genre is often presented as emphasising the failure of modern law to achieve justice, with the superhero's vigilante justice presenting a critique of the law. ${ }^{24}$ However, the vision of justice 'beyond' the law that the superheroes present is one that is attached to legality, and the genre engages in a form of visual jurisprudence. ${ }^{25}$ That is, as I have argued elsewhere, it is not so much an overthrowing of the failed legal system that superheroes desire but rather its supplementing and completion. ${ }^{26}$ At the same time, a fundamental tension remains between the superhero's vigilante methods and modern legality's focus on the rule of law, a system of justice and due process. As has been pointed out by others, the figure that most reflects this tension is Daredevil. ${ }^{27}$ This is not so much because of his role as superhero-being both blinded and receiving superpower enhancement of all his other senses as a result of being hit by radioactive waste when a kid-but rather because of his alter-ego Matt Murdock's role as a lawyer. ${ }^{28}$ It is Daredevil's duality — both superhero and lawyer-that provides a way of reading superhero comics emblematically, compressing meaning into not only the characters and narratives, but also the multimodal conjunction of image and text itself. ${ }^{29}$

Such an emblematic reading is explicitly evoked in the comics with a number of images directly connecting Daredevil to that most familiar of legal emblems, Justitia, or Lady Justice. The cover by Bill Sienkiewicz of Issue \#5 of David Hine's 2005 narrative arc 'Redemption' (see Figure 1), pictures Daredevil kneeling in despair in front of a stylised image of Lady Justicerepresenting a story where Matt Murdock fails to save a wrongly accused from death row, in part because of Daredevil's inability to catch the real killer. ${ }^{30}$

\footnotetext{
${ }^{17}$ Goodrich, Legal Emblems, xviii and xxi.

${ }^{18}$ Goodrich, Legal Emblems, 3.

${ }^{19}$ As Goodrich notes, "It is against this background that the specific imagery of justice and law needs to be reconstructed and viewed as a coherent visual tradition and transmission of legality as and in pictures." Goodrich, Legal Emblems, 19.

${ }^{20}$ See Tranter, "Law, the Digital and Time."; Sleep, "Visiocracy of the Social Security Mobile App."

${ }^{21}$ Goodrich, Legal Emblems, 20.

${ }^{22}$ Goodrich, Legal Emblems, 20.

${ }^{23}$ Bainbridge, "This is the Authority."; Manderson, "Trust Us Justice.”; Peters, “'Seeing' Justice Done.”

${ }^{24}$ Sharp, "Riddle Me This," 353; Bainbridge, "This is the Authority," 457; Manderson, "Trust Us Justice," 33. See also Peters, " 'Seeing' Justice Done."

${ }^{25}$ See, in particular Bainbridge, "This is the Authority."; Bainbridge, "What is So "Super'."; Giddens, "Navigating the Looking Glass."; Giddens, "Natural Law and Vengeance."; Giddens, "Anderson v Dredd."; Mitchell, "Paradoxes and Patriarchy."; Phillips, "Cultural Criminology and Kryptonite.”; Phillips, Comic Book Crime; Sharp, "Riddle Me This.”; Sharp, " 'Fear' and 'Hope'.”; Vollum, "Portrayal of Crime and Justice."

${ }^{26}$ Peters, "Beyond the Limits."; Peters, “'Seeing' Justice Done."

${ }^{27}$ Taslitz, "Daredevil and the Death Penalty.”; Bainbridge, "This is the Authority."; Sharp, "Riddle Me This.”; Spanakos, "Hell’s Kitchen's Prolonged Crisis."; Ferris, "Devil's Advocate."; Young, Miller's Daredevil; Henderson, "Legal (and Moral) Vigilante."; Rosen, "Lawyer as Superhero."

${ }^{28}$ Daredevil, created by Stan Lee, first debuted in April, 1964. For the classic tales of his origin see: Lee, "Daredevil \#1: The Origin of Daredevil.”; Miller, Daredevil: The Man Without Fear. For an excellent analysis of Miller's contribution, see Young, Miller's Daredevil.

${ }^{29}$ Giddens, On Comics and Legal Aesthetics.

${ }^{30}$ Hine, Daredevil: Redemption.
} 


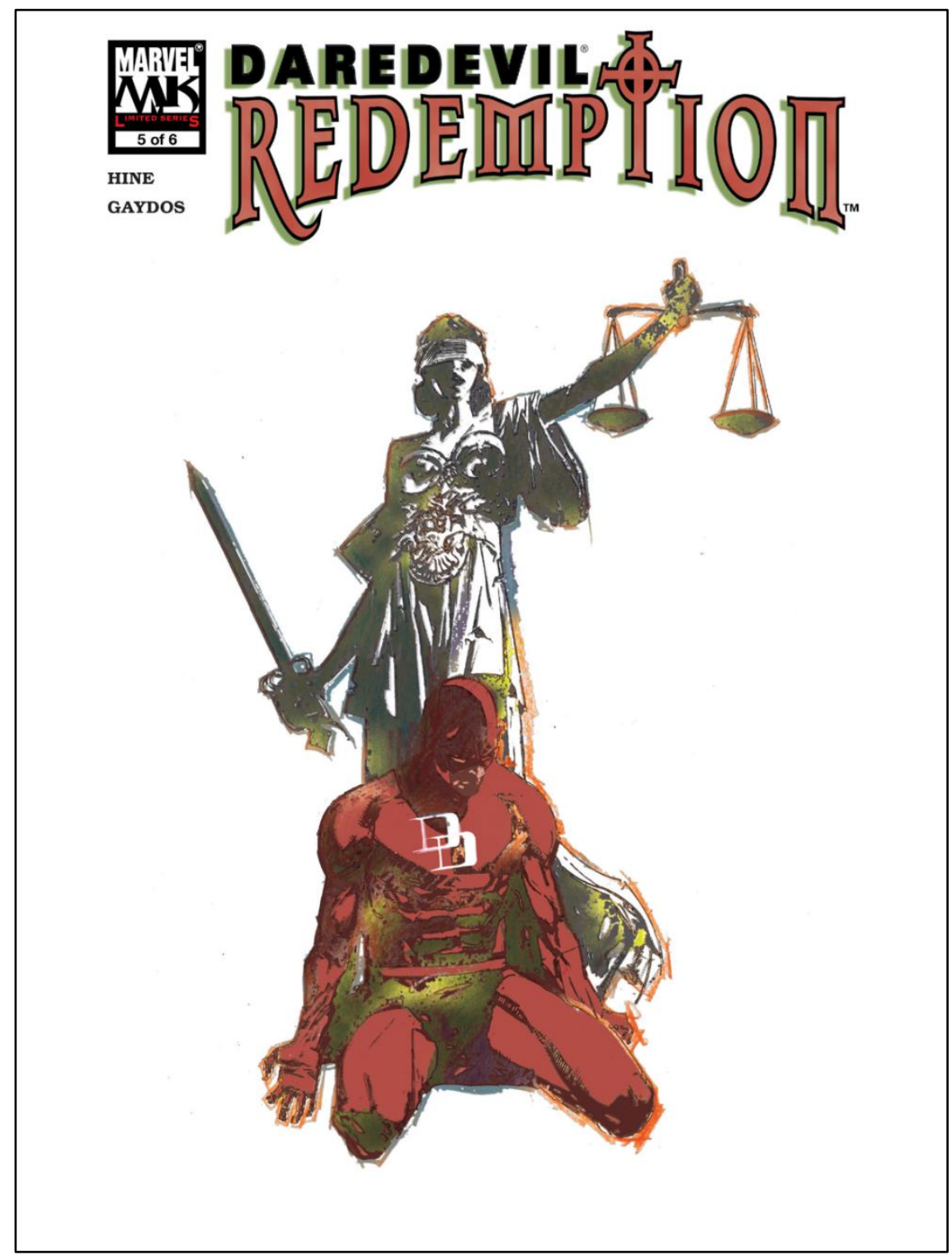

Figure 1. Cover from Hine Daredevil: Redemption \#5, 2005.

Image credit: Bill Sienkiewicz. (c) 2016 Marvel Characters Inc.

This image evokes tragedy and Daredevil's failure to achieve justice. Both figures on display succumb to justice's blindnessjustice was not done, the law failed, even when a heroic effort had been put in place. The focus of the cover of Issue \#3 of the 2014 Matt Waid run on Daredevil is also of a statue of Justitia, blindfolded with sword and scales (see Figure 2). ${ }^{31}$ In this cover, however, the two basins of the scales form the eyes of a silhouette of Daredevil in the sky behind. Rather than Daredevil being presented in a pose of failure, subordinate to Justitia's blindness, Daredevil hovers behind Lady Justice herself — the balancing of her scales forming the eyes through which Daredevil can 'see' despite his blindness. ${ }^{32}$

\footnotetext{
${ }^{31}$ Waid, Daredevil Vol. 1: Devil At Bay.

${ }^{32}$ See discussion in Peters, "Theological "Seeing" of Law."
} 


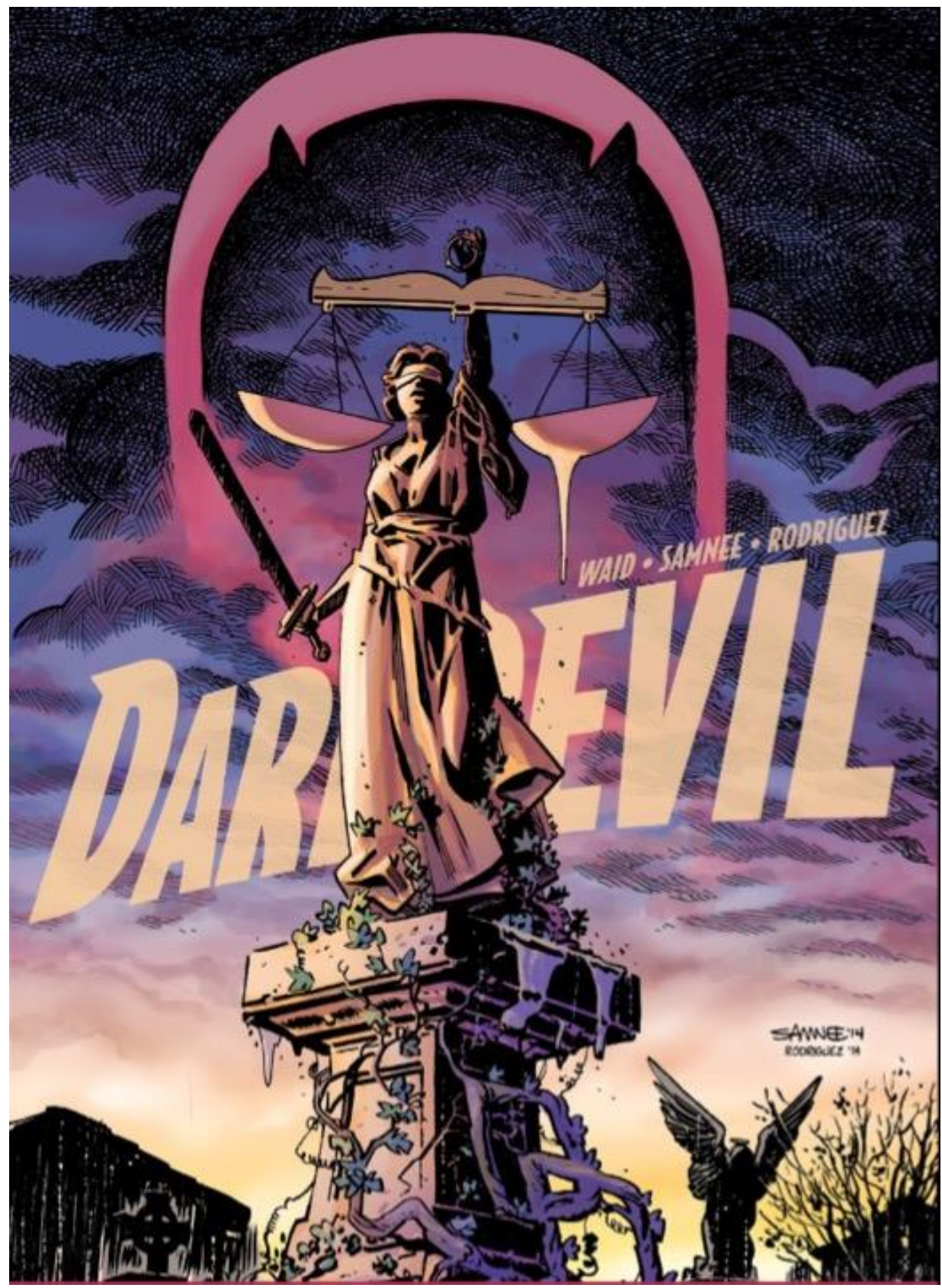

Figure 2. Cover from Waid Daredevil Vol. 1: Devil at Bay \#3, 2014.

Image Credit: Chris Samnee and Javier Rodiguez @ 2014 Marvel Characters, Inc

This second image visually captures an essential aspect of the connection between modern law and justice. As Sherwin has noted, in "the visual economy of law justice hovers, beyond the field of vision, like an uncanny enigmatic presence. It haunts us. Always unrealised, always beyond our grasp - and yet, it is justice that animates law, lending it significance." $" 33$ This image visually represents this, with Daredevil literally hovering behind Justitia as an "uncanny, enigmatic presence" that is haunting us. What Sherwin points to is the way in which there is a "phantasmal presence" that haunts the law-or that if such a presence is absent, then the law is "valid, but lack[s] significance." 34 The image encapsulates the superhero genre's satirical critique of the law, the concern over a legalism that abandons justice and the need for a populist and vigilante figure to fulfil such a justice.

\footnotetext{
${ }^{33}$ Sherwin, "What Authorizes the Image," 337.

${ }^{34}$ Sherwin, "What Authorizes the Image," 337.
} 
This claim to a popular justice reflects an aspect of what Eric Santner refers to as the "royal remains," that "phantasmal presence that invisibly bestows legitimacy upon law." ${ }^{25}$ The vigilante body of the superhero and their desire for justice functions not simply as a supplement to the law, but rather as a necessary authorising presence - the sublime 'royal remains' born by 'the People' and needed to sustain and legitimise modern legality.

Daredevil and Justitia are, of course, both images or representations of 'blind justice', taking up the emblem of the blindfold. Yet the connection between the two is complex. The modern depiction of Justitia's 'blind justice' focuses on the importance of modern law's impartiality, of due process as a means for ensuring the formality and objectivity of the law, ignoring the wealth, status and particular identity of the person brought before it so that all are equal under law. However, it is these aspects of the law and legal system that the superhero in general — and Daredevil in particular_critiques, arguing that the law is fallible and its emphasis on due process results in a failure to protect citizens that gives rise to vigilantism, popular justice and the need for the superhero. ${ }^{36}$ While this would appear to present a fundamental conflict in depictions of law and justice, the blindfold that is currently attached to a particular vision of modern legality had its origins in a critical or satirical mode.

As has been well rehearsed, Justitia as the esteemed figure of justice, with the scales representing the balance and harmony of law, the sword its force and the blindfold its impartiality and neutrality, was not originally depicted with the latter adornment. ${ }^{37}$ Early images of justice, whether Roman or medieval, were unveiled, with judgments made on the basis of visual evidence and clear-sightedness. ${ }^{38}$ The first depiction of Lady Justice with blindfold comes from Sebastian Brant's 1494 The Ship of Foolsa series of satires with accompanying woodcuts. Verse 71, as Desmond Manderson notes, encompasses a critique of the legal profession, their corruption and their attempts to "blind the truth." ${ }^{39}$ The accompanying image, often attributed to Albrecht Dürer, however, depicts not truth but justice as being blinded by the figure of the fool - thus emphasising "the animus of lawyers, actively blindfolding justice, the better to achieve their own foolish ends." 40 This woodcut functions in a critical mode. The blindfold here, as was consistent with its contemporary meaning, is a negative symbol, a symbol of error or of being blinded. ${ }^{41}$ Such is a critique of the law and, in particular, the development of modern law with a legal profession trained in interpretation and the legal technicalities that came with it. ${ }^{42}$ Quite quickly, however, the blindfold as a marker of critique became a positive emblem, signalling impartiality, objectivity and equality - treating like case as like, and ignoring the personal status of those who come before the law. It was with the Protestant Reformation's critique of the church's own connection to the law, its own legalism, that a new theory of law emerged: legal positivism, with its treating of "the law of the state as morally neutral, a means and not an end."43

For Manderson, what is important is not the way the blindfolded reflected changing times-legal modernity and the Reformation - but rather how it enabled them:

The myth of blind justice combines elements of the legal reformation that preceded it, and of which it was originally critical, with elements of the religious reformation that succeeded and substantially modified it. The image can be seen to hold together these two contradictory elements, uniting them into a new coherence. It accommodates itself to a profoundly new legal environment by incorporating references to the backward looking critique within a new discourse of separation. ${ }^{44}$

The image of the blindfold is, therefore, what Manderson calls a "transitional myth" that "does not just emerge during [emphasis in original] a critical time of transition, but ultimately enables it, representing in the same sign first one set of characteristics and then the opposite. ${ }^{45}$ What changed was not the signifier, but the signified - the meaning that it portrayed. ${ }^{46}$

Given the blindfold's function as a transitional myth, it is perhaps less surprising that it has become associated with the superhero's mask and, in particular, the figure of Daredevil. Bainbridge has pointed out that superheroes enjoy greatest popularity during times of transition and uncertainty_war, armed conflict, economic or cultural crisis. He argues that in these

\footnotetext{
${ }^{35}$ Sherwin, "What Authorizes the Image," 337, referring to Santner, Royal Remains.

${ }^{36}$ This is the crux of Bainbridge's argument that the superhero is a signifier of 'substantive justice'. Bainbridge, "Call to Do Justice."; Taslitz, "Daredevil and the Death Penalty."; Sharp, "Riddle Me This."; Henderson, "Legal (and Moral) Vigilante."

${ }^{37}$ Douzinas, "Prosopon and Antiprosopon.”; Jay, "Must Justice Be Blind.”; Resnik, Representing Justice; Goodrich, "Foolosophy of Justice.”; Manderson, "Metastases of Myth."

38 Jay, "Must Justice Be Blind," 19.

${ }^{39}$ Brant, Ship of Fools, 236; cited by Manderson, "Metastases of Myth," 213.

${ }^{40}$ Manderson, "Metastases of Myth," 213.

${ }^{41}$ Goodrich, Legal Emblems, xxiv-xxvi; Manderson, "Metastases of Myth,” 216; Jay, "Must Justice Be Blind,” 20.

${ }^{42}$ Berman, Law and Revolution; Manderson, "Metastases of Myth."

${ }^{43}$ Berman, Law and Revolution, 29; Manderson, "Metastases of Myth," 215.

${ }^{44}$ Manderson, "Metastases of Myth," 216.

${ }^{45}$ Manderson, "Metastases of Myth," 216.

46 Manderson, "Metastases of Myth," 216-217.
} 
contexts the superhero becomes a "reliable signifier of justice in an increasingly uncertain world." 47 The superhero's embodied notion of justice is contrasted with a nebulous notion of law and its intermittent connections with justice. Yet, if we examine the history of the superhero from, as Bainbridge does, the first appearance of Superman in Action Comics, we find tensions within this supposed representation of justice. The early depictions were not a lauding of justice beyond the law, the form of exceptionality that we associate with the superhero today. Rather, there was a focus on supporting and endorsing the law, and the need to fight social crimes such as political corruption, domestic violence and mob lynching. ${ }^{48}$ The superhero as the figure beyond the law arose later. If we take Manderson's point seriously, then the superhero is not simply a reflection of legal exceptionalism but rather facilitates its emergence. The transitional myth is one that is able to take underlying cultural oppositions (law and justice, letter and spirit, particular and general, local and universal, spiritual and temporal) and find a new accommodation - transforming these dichotomies from the underlying critique of modern law to the condition of its authority. ${ }^{49}$ It is in this light that we should read the emblematic nature of Daredevil, with its representation not only of the blindfold but of blindness itself. The accident that caused Murdock's blindness when he was a boy did not produce in him so much a failure to see but, through the radioactive enhancement of his other senses and his radar-like capabilities, the ability to see otherwise. Such would seem to literalise one of the emblem tradition's interpretations of the blindfold. Goodrich discusses, for example, an image from Barthélemy Aneau's Jurisprudentia of 1554 in which a fully sighted Justitia is situated on a dais "declaiming from the book of the law" to a "muddled, blindfolded assembly of lawyers" situated below her. ${ }^{50}$ While Goodrich does not pass up the opportunity to have a dig at lawyers' inability to see (their "confusion, limitation and, quite simply lack of vision"), Aneau's image focuses rather on the need for severe and lengthy training to understand both law and justice. ${ }^{51}$ The blindfold, thus, marks a turning away from the deceptiveness of sight and a looking elsewhere, "to use the inner eye, the eye of the spirit" - to search for law inwardly. ${ }^{52}$ Such is literally figured in Daredevil's blindness, where his radar sense and enhanced abilities enable a greater seeing than the physical eyes of those around him. These abilities are deployed as means of revealing truths otherwise hidden: the ability to hear conversations from great distances and through walls; to determine whether someone is lying or telling the truth based on their physiological characteristics that he can sense (the speed of their heartbeat and exuding of sweat). Such abilities indicate both the fallibility of the eyes and the risk of their deception while indicating that the use of the 'inner eye' is more revealing, more accurately able to capture and judge the truth.

Daredevil's suit, mask and helmet also function emblematically, proclaiming his identity as the 'Devil of Hell's Kitchen'. The identification with the devil - the horns that are the signature feature on the top of his helmet, along with the red colouring of the suit—would seem strange for an on-again off-again Catholic. Yet the demon horns have an apotropaic function, a warding off of evil spirits that parallels the gargoyles on medieval and Gothic churches - statues that Daredevil is sometimes seen clinging to in Hell's Kitchen. Daredevil's horns are, thus, a theatrical attempt to project fear into the criminal underworld. ${ }^{53}$ Such allusions are furthered by the "demonic red lenses" or visors that feature in his mask, ${ }^{54}$ and return us to the significance of the depiction of eyes and vision. For the comic reader or viewer, the irony of this depiction is obvious-the presentation of a mechanism for seeing for someone who cannot see. At the same time, the feature of eyes both goes to a sense of what is ordinarily expected in looking at the face, and also to the deception that the dual identity requires (concealing the fact that Daredevil is, like Murdock, in fact blind - a fact not generally known). ${ }^{55}$ Yet the actual depiction of these visors produces a sense of an absence of the eye - not simply covering it over so that it cannot be seen, but an impression that it is not there. Such a visual rendering itself features in the emblematic tradition, and it is the depictions of both the Prince and Justitia with eyes absent or gouged out (along with maimed or severed hands) that are a prelude to the positive images of blindfolded justice. ${ }^{56}$ The interchangeableness of depiction that then arises - between eyes gouged out and the blindfold that covers them-is reflected in inverted form in certain Daredevil backstories where, before taking up the suit and mask, he is literally wearing a blindfold or black bandana that covers his eyes. ${ }^{57}$

\footnotetext{
${ }^{47}$ Bainbridge, "Call to Do Justice," 747.

${ }^{48}$ Bainbridge, "This is the Authority," 455-456; Bainbridge, "Call to Do Justice," 748-750.

${ }^{49}$ Manderson, "Metastases of Myth," 219.

${ }^{50}$ Goodrich, Legal Emblems, 147.

${ }^{51}$ Goodrich, Legal Emblems, 149.

${ }^{52}$ Goodrich, Legal Emblems, 161.

${ }^{53}$ On the apotropaic function of the superhero's costume, see Weltzien, "Masque-ulinities," 243-244.

${ }^{54}$ Brownie, Superhero Costume, 39.

55 Though, as Alaniz has pointed out, there is also something unique in the way in which Murdock involves a form of 'passing' as blindthat is, instead of the usual attempt at passing which attempts to hide a physical disability, Murdock has to actually 'pass' as his physical disability: a form of deception in that he is blind, but also can 'see'; he has to then pretend to be blind. Alaniz, Death, Disability and the Superhero, 73-74.

56 Goodrich, Legal Emblems, 170-171.

${ }^{57}$ In these backstories (including in the Netflix television series), Murdock's early vigilante escapades show him not in a suit but dressed in black with a black bandana across his head and covering his eyes. This would seem to provide a pre-figurative basis for reading the mask itself as a blindfold - the bandana operates not only as a means of concealing Murdock's identity, but also a projection and communication of blindness.
} 


\section{The Superhero Identity and Law: Soule as Modern Alciato}

This emblematic reading of Daredevil finds its apogee in my source text for this article, the run on Daredevil by our modern Alciato, the lawyer-turned-comics-writer Charles Soule. The significance of Soule's run, and in particular the narrative arc 'Supreme', which I will focus on, is the way in which he takes up, but then inverts, the dichotomy of Daredevil's dual personas and their relation to the law-presenting, in the end, the lawyer as superhero. The emblematic nature of this is made explicit in the concluding issue of Soule's run (as part of the story 'The Death of Daredevil', told over four issues), where we find a representation not of Daredevil and Justitia, but Daredevil as Justitia (see Figure 3). ${ }^{58}$

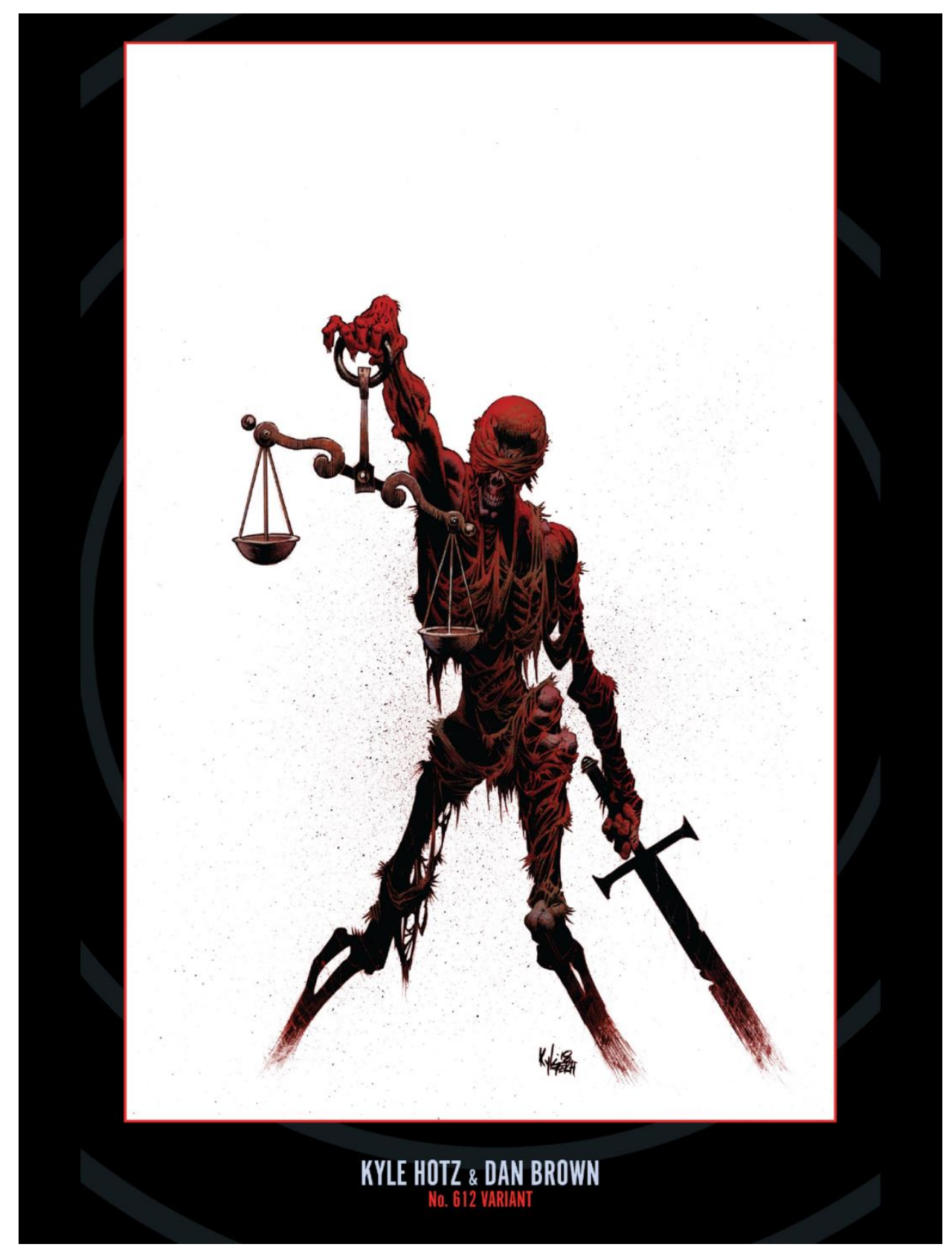

Figure 3. Alternate Cover Art for Soule Daredevil: Back in Black Vol. 8: Death of Daredevil \#612, 2018

Image Credit: Kyle Hotz and Dan Brown (C 2019 Marvel

$\overline{{ }^{58} \text { Soule, Daredevil: Back in Black Vol. } 8 .}$ 
The image by Kyle Hotz and Dan Brown appears as one of the alternative covers for the final narrative arc that, as the title implies, concludes with the death of Daredevil (though, as with all commercially successful superheroes, death is never the end-with Chip Zdarsky since taking over writing duties on the series). ${ }^{59}$ Instead of Daredevil kneeling and subordinate to a justice he was unable to obtain, or a hovering and haunting presence seeking to judge and legitimate the 'doing' of justice, here we find a skeletal version of Daredevil holding up the scales in his right hand, with a chipped and battle-worn sword in his left. The usual slick and tight-fitting costume is in tatters, hanging down and bearing visual similarities to the robe that so often adorns Justitia. This tattered suit-cum-robe fails to reach to the ground, showing skeleton legs barely able to hold up the body and the literal weight of doing justice. The mask, which retains its signature horns, is covered by a red blindfold or bandana, merging together the symbolism described above-here the mask literally is Justitia's blindfold. This 'hellish' figure of Justice symbolises that only in death is Daredevil able to become the emblem of what he fought to achieve.

Much of this final narrative arc in Soule's run is a dream (a plot point not revealed until the moments before his death in the final issue) in which Daredevil is engaged in an investigation to reveal the election fraud that enabled Wilson Fisk, the Kingpin, to be elected Mayor of New York City. ${ }^{60}$ The story involves the usual superhero theatrics, but the investigation comes to a head with a trial in which not only Daredevil, but all the heroes of New York-Captain America, Thor, She-Hulk, Spider-Mantestify against Fisk. While this trial is all part of Daredevil's dream, the ability for the superheroes to testify in court is not. Rather, it is made possible as a result of the Supreme Court case, People vs Slugansky, argued and won by Matt Murdock in the 'Supreme' narrative arc, which is the centrepiece of Soule's run. ${ }^{61}$ In that case the Court ruled that superheroes can be treated as analogous to confidential informants and allowed to testify in court (including admitting evidence gathered as a result of superpowers, such as Daredevil's super-hearing) without revealing their secret identity. Soule thus progresses a particular vision of the superhero's relationship to the law: instead of vigilantes achieving a justice beyond the law, they should have a legitimate and 'legal' role in apprehending and convicting criminals. ${ }^{62}$ This bringing of the superhero within the law differs from previous attempts-Superman's subordination to the state in Frank Miller's The Dark Knight Returns, or the Superhero Registration Act of the Marvel Civil War 'event' ${ }^{63}$ _ by limiting the operation of the confrontation clause encompassed in the Sixth Amendment to the United States (US) Constitution, so that the superhero can testify and provide evidence without revealing their identity. That is, by retaining and rendering legal the superhero's dual identity. ${ }^{64}$

The dual identity of the superhero has been one of the central conceits of the genre since its inception-a conceit called into question in the Brian Michael Bendis and Matt Waid runs on Daredevil. In Bendis's run, the newspaper The Daily Globe published Daredevil's identity as Murdock. Murdock's response was not to come clean but to flatly deny the allegation and, in a fundamental breach of ethical and legal standards, threaten to sue the paper for libel. The rumours of his dual identity proceed to cause problems both for Daredevil and Murdock, with criminals and clients using the law against him. Waid's run took this issue further with Murdock eventually admitting publicly and under oath to being Daredevil. While the New York State Supreme Court acknowledged and even thanked Murdock for his "service to the cause of justice both publicly and privately," he was disbarred and moved to San Francisco to continue his now public dual roles as costumed superhero and lawyer. ${ }^{65}$ As Louis Michael Rosen notes, these narratives present a meditation on the range of legal and ethical problems of a lawyer-byday, superhero-by-night. ${ }^{66}$

In contrast to these continuous explorations of the ethical quandaries of the Daredevil/Murdock duality, Soule begins his run by rebooting this narrative motif, with the first issue seeing Murdock back in New York and working for the District Attorney's office ${ }^{67}$ As the result of a fantastically ludicrous plot point involving the alteration of the memory of every person on the planet (only revealed in the later narrative arc 'Identity'), everyone but his friend and previous law partner, Foggy Nelson, no longer remembers that Murdock is Daredevil. ${ }^{68}$ These extreme narrative gymnastics are deployed by Soule explicitly to allow the reemergence of the dual but separate identities, reinstating the fundamental tension of Daredevil/Murdock which goes to the

\footnotetext{
${ }^{59}$ Zdarsky, Daredevil by Chip Zdarsky Vol. 1.

${ }^{60}$ Which occurred in Soule, Daredevil: Back in Black Vol. 6.

${ }^{61}$ Soule, Daredevil: Back in Black Vol. 5.

${ }^{62}$ A point made by Murdock's employer, the District Attorney, before Murdock proceeds with the original case. See Soule, "Daredevil \#21 'Supreme' Part 1."

${ }^{63}$ See Miller, The Dark Knight Returns; Millar, Civil War.

${ }^{64}$ As the niche 'law and superhero' corner of the blogosphere notes, there are traditionally a number of issues with the idea of superheroes appearing in court. See Davidson, "Superheros and Alter-Egos.”; Daily, "Confrontation Clause.”; Ingersoll, "The Law Is a Ass \#442.”; see also Ingersoll, The Law Is A Ass, in particular, "Docket 1: Batman."

${ }^{65}$ Waid, Daredevil Vol. 3. For a summary of these narrative shifts across the runs written by Brian Michael Bendis, Ed Brubaker and Matt Waid, see Rosen, "Lawyer as Superhero."

${ }^{66}$ Rosen, "Lawyer as Superhero."

${ }^{67}$ Soule, Daredevil: Back in Black Vol. 1.

${ }^{68}$ Soule, Daredevil: Back in Black Vol. 4.
} 
emblematic nature of the character. The diegetic reason for Murdock's return to New York is his ultimate plan to bring a case that will deal with, legitimate and protect the superhero's secret identity.

The issue raised in the case — whether a superhero can appear and testify in court without revealing their secret identity — would seem to contravene both the common law right to confrontation and the US Sixth Amendment. ${ }^{69}$ The right of confrontation includes "the right of an accused to know the true identity of his or her accusers, the right to be present during their testimony and the right to test their evidence through cross-examination."70 US judicial consideration of the justifications of the confrontation clause has emphasised the importance of face-to-face confrontation, both so that the witness can look the defendant in the eye (on the assumption that it is harder to lie to someone's face) and so the judge and jury can see the witness's demeanour and determine their credibility (despite the questionable accuracy of such judgments). ${ }^{71}$ The comic focuses on one of the key exceptions to this right, the informer privilege, which seeks to ensure a flow of information to the police and prosecution by allowing them not to disclose an informer's identity. ${ }^{72}$ The US Supreme Court limited this privilege in the key case referred to in the comic, Roviaro v. United States, noting that "[w] contents of his communication, is relevant and helpful to the defense of an accused, or is essential to a fair determination of a cause, the privilege must give way." $" 73$ One of the problems with the implied line of reasoning in the comics is that the informer privilege applies to the government, not the informer, and it does not normally apply to those testifying in court. ${ }^{74}$ At the same time, as the trial judge notes, this specific question fits within a larger concern about anonymous testimony ${ }^{75}$ — with a number of cases extending some anonymity to undercover police officers and intelligence agents, allowing them to testify under their pseudonym (particularly if this is the only name the accused has known them by). ${ }^{76}$

While these issues are alluded to in the scenes depicting both the trial and Murdock's later appeals up to the US Supreme Court, what is significant is that the initial ruling by the trial judge was that the witness was not anonymous, but rather a very well known public figure: Daredevil. What is being called into question is, thus, not the ability to testify anonymously, but the nature of the identity of the person testifying. The judge, therefore, says that he will allow the witness to testify as Daredevil, but only if it can be evidenced that he is actually Daredevil. When the judge explains this, Daredevil's glib and immediate response points to the theatrical nature of the superhero identity: "uh...did you miss the suit, Your Honor?", to which the judge sternly retorts, "anyone can put on a suit, Mr. Devil" (see Figure 4). Mr Baden, acting on behalf of the defense, then challenges Daredevil to prove who he is, to which Daredevil proceeds to provide examples of his powers - he can hear a phone call being undertaken in the corridor outside and he can smell the defense counsel's partially digested lunch. Baden dismisses both examples as hardly proof, given that the lady on the phone could have been a plant, and that he had eaten lunch in a public restaurant where someone could have seen him and reported back to Daredevil.

\footnotetext{
${ }^{69}$ See the Sixth Amendment to the United States Constitution, which provides that in all federal criminal prosecutions the "accused shall enjoy the right... to be confronted with witnesses against him." See discussion in Lusty, "Anonymous Accusers," 361-362, 376.

${ }^{70}$ Lusty, "Anonymous Accusers," 361-362.

${ }^{71}$ For discussion of these points, see Karsai, "Rethinking Witness Anonymity," 56-60, 78-81.

72 See Saltzburg, "Informant Privilege.”; Harrison, "Law Relating to Informer Privilege.”; Mares, "Balancing Public Interest."

${ }^{73}$ Roviaro v United States, 353 U.S. 53, 60-61 (1957). For elaboration, see "Informer Privilege: What's in a Name."; Saltzburg, "Informant Privilege."

${ }^{74}$ Having said that, there has been an extension in some jurisdictions, by way of analogy, to certain witnesses including undercover police officers. See Jarvie v Magistrates' Court of Victoria [1995] 1 VR 84. Note the critical discussion of the judgment by Lusty, "Anonymous Accusers," 404-407.

${ }^{75}$ As Karsai has noted, despite most scholarly considerations arguing that the law has not (and should not) permit anonymous testimony, there are a range of examples where this has been allowed. Karsai, "Rethinking Witness Anonymity."

${ }^{76}$ See the extensive list of examples provided by Karsai, "Rethinking Witness Anonymity." The circumstances justifying witness anonymity are based on imminent risk of harm to the witness or, in the context of, for example, undercover police officers and intelligence agents, the greater harm of their identities being revealed.
} 


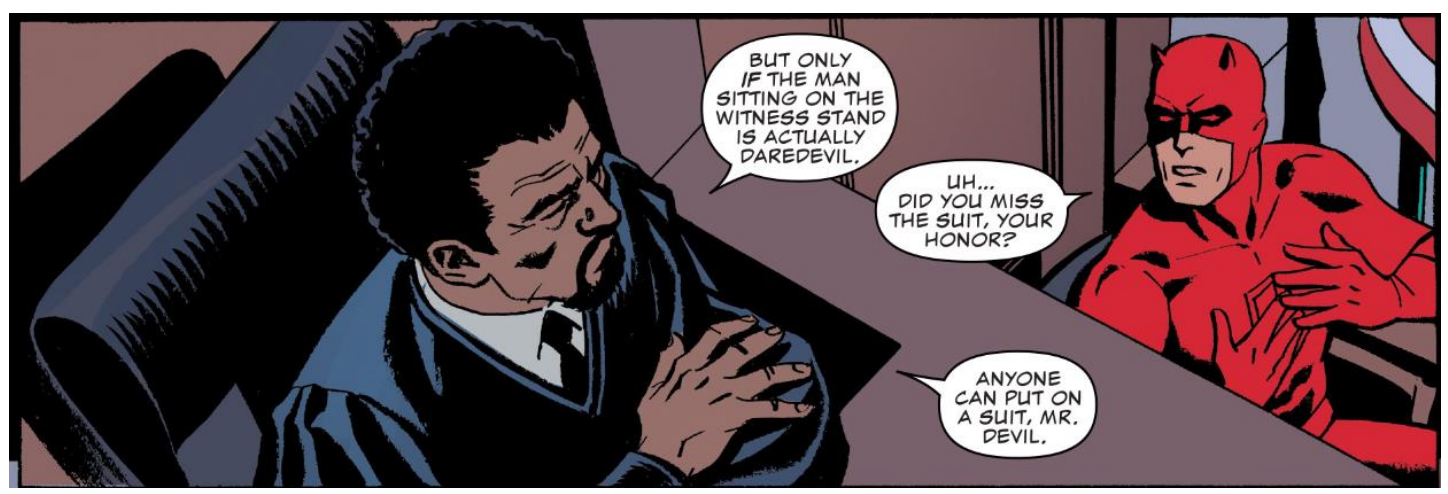

Figure 4. Panel from Soule's Daredevil: Back in Black Vol. 5: Supreme \#21, 2017.

Image Credit: Goran Sudžuka (C) 2017 Marvel Characters, Inc

At this point, one could raise (as often is done) concerns about the stylistic and narrative liberties taken by Soule in his presentation of the law, and whether this detracts from the accuracy of the legal representation. ${ }^{77}$ However, to focus on the legal accuracy of these depictions is to miss the point and to misdiagnose the emblematic status of these images. For while the emblem as a species of devise did encompass a process of legislating through the image — a 'making law visible' —it was not in terms of a literal depiction of law, but rather involved metaphorical, rhetorical and didactic use of images. ${ }^{78}$ Such was to recognise the unique form of apprehension that the image invited, one that is itself distinct from the word, but also that is not necessarily specifically concerned with deceptiveness or literal inaccuracies. In this sense, what the trial scene from 'Supreme' presents is not an instruction in the specifics of legal procedure but rather a visual meditation on the question of the legal recognition and apprehension of the individual - the construction of what Goodrich refers to as "the optical apparatus of the person." $" 79$ While the substantive legal issues of the case turn on questions of due process, the right to a fair trial and the extent of the confrontation clause, the question of how one evidences that they are 'really' their persona, raises a larger question about the nature of the image — what is it that we are seeing?

\section{The Superhero Image: The Political Theology of Sovereignty and the Optical Apparatus of the Person}

In the diegetic questioning of whether the man sitting in the witness stand really is Daredevil, a masked persona and superhero, the concern is about the ability to evidence the identity of this person through a determination of his amplified abilities of biological apprehension. Extra-diegetically for the viewer, however, it is not so much that we are seeing a physical body that is adorned in a mask and suit, but rather that all that is drawn is the mask and suit (with only a small amount of the face visibly presented). Any embodied presence underlying this figurative depiction is one that is 'seen in' by the viewer. In this fashion, the image presents to us more than its own depiction because of the way in which we see with and beyond it. ${ }^{80}$ Despite the fact that all the viewer literally 'sees' is the image of a suit and mask, what we apprehend is Daredevil who we know to be Matt Murdock wearing a mask. This level of 'seeing in' is reflective of the way in which the image functions in a web of visual discourse, a social interpretive context interrelated with other images beyond it-both within the particular comic here, but also in relation to the superhero genre and the range of other images through which we interpret it (including the specifically legal ones, to which I will return in the next section) ${ }^{81}$ As Manderson notes, "[i]mages are representations that, at the same time that they are unquestionably reminders of an absence — both the absence of the representing subject and of the represented objectare also unmistakably present [emphasis in original] to viewers." ${ }^{22}$ Goodrich, along similar lines, describes the image as:

\footnotetext{
${ }^{77}$ See, for example, Bob Ingersoll's critical reviews: Ingersoll, “The Law Is a Ass \#442.”; Ingersoll, "The Law Is a Ass \#443.”; Ingersoll, "The Law Is a Ass \#444.”; Ingersoll, "The Law Is a Ass \#445." Rosen's comprehensive analysis of legal issues in the Daredevil comics also tends to focus on "lessons that readers and television audiences may be absorbing," and is, therefore, concerned about the accuracy of the depiction of the law — a point Henderson also raises. Rosen, "Lawyer as Superhero," 381. Henderson, "Legal (and Moral) Vigilante."

78 Goodrich, Legal Emblems, 77.

${ }^{79}$ Goodrich, "Theatre of Emblems."

${ }^{80}$ Alloa, "Seeing-as, Seeing-in, Seeing-with.”; Peters, “Theological 'Seeing' of Law."

${ }^{81}$ Manderson, "Imaginal Law," 3-4.

82 Manderson, Danse Macabre, 17.
} 
[T]he mark of an absence, the sign of something, or more properly of some non-thing, that is not present, and hence its truth and its falsity. In being false, in being mere semblance, however, the image offers an index, a reference and path to a higher and longer lasting verity. ${ }^{83}$

The question, therefore, of whether Daredevil is really himself, goes to the nature of the truth of the image that is being presented and the law's ability to judge it.

This question of the truth or verity of the image can be understood at two levels. First, the superhero is a figure that functions explicitly through a range of visual paraphernalia that mark the presence of his or her identity: the mask, cape, costume and other trademarked and highly visible devices. Sometimes referred to as the superhero's 'brand' or 'image', these devices reflect the way in which the superhero functions through imagery, and it is the efficacy of such imagery that is being questioned by the judge in the case at hand. As superhero scholar Peter Coogan, has pointed out, this use of imagery forms one of the most distinctive features of the superhero genre: the unique superhero identity that is normally encompassed in a codename, costume and insignia or chevron (often worn on the chest). ${ }^{84}$ While early pulp and other heroes made use of costumes to mask or hide their identities, superheroes deploy their visuality to explicitly “proclaim” their identities. Superman's ' $\mathrm{S}$ ' chevron, Batman's bat symbol, Spider-Man's unique costume and Daredevil's horns and 'DD' insignia are "iconic representations of the superhero identity" 85 that come to stand in for the superhero. The insignia attached to their branded items create a visual link to the superhero persona, acting as a mark of an absence, functioning even when the physical embodiment of that persona is not there. ${ }^{86}$

We can trace this visual deployment of identity to the history of the law of images, which finds its earliest roots in the legal art of armoury or symbola heroica - literally symbols of the heroic: "the manufacture and circulation of the signs and visual symbols of the classical law of place, role, dignity, title and office." ${ }^{87}$ The military importance of these marks related to the ability to see and distinguish friend from foe in the 'theatre of war', with a systematised "ranking of all the visible elements used to demarcate, distinguish, and transmit the identity and rank of their bearer." ${ }^{88}$ The earliest work on insignia focused on "legal classification, ordering, and regulation with criminal sanctions for false representations and for theft of insignia and marks." ${ }^{89}$ This involved attempts to limit confusion or harm resulting from illegitimate use, but it was also situated within the broader context of the nature of the legitimacy of signs and their authorisations. The authorised administration of a territory was linked to the authorisation of the image, the visible functioning of legal and sovereign authority throughout a domain, which required "the images of honor, virtue, office, rank, local and national affiliation that define the administration of a territory." $"$ The superhero's deployment of insignia and paraphernalia are a modern reflection of the "visible dignities and offices" that present a sign of sovereignty or authority that is not physically present. ${ }^{91}$

At the same time, the association of Daredevil with his suit would also appear to reflect a particular aspect of the early modern political theology of absolute sovereignty, which, as Louis Marin famously pointed out, functions only through the image of the sovereign..$^{2}$ The portrait of the king does not only stand in for that which is not there, but it is the representation itself that

\footnotetext{
${ }^{83}$ Goodrich, Legal Emblems, 29.

${ }^{84}$ The superhero identity is one of three key components that make up Coogan's definition of the superhero (the others being a pro-social mission and some sort of superpower), which he bases upon the judgment of Justice Learned Hand in Detective Comics Inc $v$ Bruns Publications Inc, 111 F.2d 432 (2nd Cir. 1940). Coogan sees the third element of identity encompassed in a code name and costume that proclaim their identity, as the most useful in distinguishing the superhero from other genres. See Coogan, Superhero, 30-39. See also Bukatman, "Secret Identity Politics."; Brownie, Superhero Costume.

${ }^{85}$ Coogan, Superhero, 33; Bukatman, "Secret Identity Politics," 114.

${ }^{86}$ Bukatman notes that one of the functions of the superhero's costume and identity is to mark a shift from an inexpressive to an expressive body. With the deployment of computer-generated imagery in modern superhero films, this expressive body is more and more a digital body. The result is that the putting on of the mask by the superhero involves a literal ceasing to be of the actor-thus, disconnecting the inexpressive and expressive bodies. Bukatman, "Secret Identity Politics," 115-116. However, it would seem that the comics always function in this way, for, while we presume that there is a figure underneath the mask, in the comics all we ever see is the mask-when we are viewing the 'liberated expressive body' of the superhero, there is literally no other body underneath.

${ }^{87}$ Goodrich, Legal Emblems, 18. For the historical connection of the superhero mask and costume to heraldry and military contexts, see Weltzien, "Masque-ulinities.”; Brownie, Superhero Costume.

${ }^{88}$ Goodrich, Legal Emblems, 59.

${ }^{89}$ Bartolus, Tractatus de insigniis et armis [1358], reprinted in Cavallar, Grammar of Signs; referred to in Goodrich, Legal Emblems, 38-39.

${ }^{90}$ Goodrich, Legal Emblems, 60.

${ }^{91}$ As Goodrich notes, the insignias of particular places were "depicted by way of listings of their visible dignities and offices, literally their viri illustris and viri spectabilis...their manifest...and notable, meaning brilliant, remarkable, famous, and even spectacular men." Goodrich, Legal Emblems, 61. On the superhero's particular relationship to the city, see Bainbridge, " 'I Am New York'."

92 Marin, Portrait of the King.
} 
provides the vision of absolute power, which the human form of the king is not able to attain. This is what Marin refers to as the 'portrait effect':

[T] he effect of representation [that] makes the king, in the sense that everyone believes that the king and the man are one, or that the king's portrait is only the king's image. No one knows that, on the contrary, the king is only his image, and that behind or beyond the portrait there is no king, but a man. ${ }^{93}$

At one level, Marin is taking up the doctrine of the king's two bodies famously studied by Ernst Kantorowicz, which distinguishes between the physical human body of the king, and the representational and sempiternal body of the king that never dies. ${ }^{94}$ However, for Marin it is the portrait or image of the king that represents not simply to his subjects but also to the king himself the vision of absolute power and unlimited sovereignty. One of the significances of the superhero genre, with its theatricality and dual identities, is the way in which the efficacy of the superhero identity functions in a similar fashion to the portrait of the king - the superhero is his or her image, and it is the efficacy of the image of Daredevil that is being called into question in this case.

Yet the superhero as a modern figure of justice renders visible not simply the political theology of the king's two bodies, but to follow Santner, the biopolitics of "the People's two bodies." 95 It is here we find a distinction between the two in terms of the relationship of the image to the individual. For Marin, the portrait of the king "is not a mask but a re-presentation." 96 It does not function in terms of the dual aspect of hiding the individual and projecting an identity. Rather, the political theology of the king presents the impossible unity of the subject within himself - a unification that can only occur in the social drawing of the image: "the monarch is absolute only in the official portrait that his subjects draw of him." ${ }^{97}$ By contrast, the theatrical nature of the superhero and his or her mask is a visible rendering of the modern split of the subject, between a sense of social recognition (the projection of the costume) and the biological human body (that which is hidden or covered over). The superhero's mask, therefore, functions as a rendering of the biopolitical apparatus of personhood-the bringing together or combining of the icononomy of governance placed upon the economy of identity, the mask of personhood upon the face of the human. ${ }^{98}$

This leads us to the second aspect of the truth or verity of the image, which is the way in which the image of the person functions within the order of the visible. Clare Pitkethly has pointed out the way in which the superhero's presence within the comic book text explicitly "incorporates the mark of absence" through the combination of text and image and the deployment of the speech bubble. ${ }^{99}$ The inclusion of words within a speech bubble goes to an incongruity or undecidability in the comics form-these are text, yet they are included within an image as an attempt to present speech. They are, thus, "writing posing as speech [emphasis in original]" and "marked by a lack, or by its very failure in this phonocentric pursuit." 100 As such, the "lifeless marks of writing issuing from the speaking subject's mouth suggest a curious process of mortification, a corruption of his or her presence." 101 Furthermore, the superhero who diegetically functions through images, extra-diegetically is only present as a subject in the process of being a mark of absence - the very lines on a page that are a material presence that is perceived, while representing a subject who is absent.

When the judge in Soule's run questions whether the individual on the witness stand is 'really' Daredevil, the reading of these "words posing as speech" function not only to mortify and question the authenticity of the presence of the subject being questioned but also the subject doing the questioning. Both judge and superhero are captured in the artistic form of the comic rendering visible an absent presence - subjects that can be seen. The fact that the context of what is being represented is a courtroom emphasises the legal nature of such capturing - the juridical drawing of the person-and brings into focus the emblematic nature of the legal functioning of personhood. As Goodrich has noted, supplementing Roberto Esposito's genealogy of the dispositif of the person, within the common law tradition "[t]he person was publically an image." 102 The etymology of the term 'persona' not only encompasses the theatrical mask but also refers "to an institutional status and role." 103 This

\footnotetext{
${ }^{93}$ Marin, Portrait of the King, 218.

${ }^{94}$ Kantorowicz, King's Two Bodies. On superheroes as figures of sovereignty, see Curtis, Sovereignty and Superheroes.

${ }^{95}$ Santner, Royal Remains, 30.

${ }_{96}^{96}$ Marin, Portrait of the King, 223.

${ }^{97}$ Marin, Portrait of the King, 237.

${ }^{98}$ Goodrich, "Theatre of Emblems," 56.

99 Pitkethly, "Pursuit of Identity," 216.

${ }^{100}$ Pitkethly, "Pursuit of Identity," 216. Drawing upon Eisner, Comics \& Sequential Art.

${ }^{101}$ Pitkethly, "Pursuit of Identity," 216.

${ }^{102}$ Goodrich, Legal Emblems, 19.

103 Goodrich, Legal Emblems, 19. See also Goodrich, "Theatre of Emblems.”; Maitland, "Corporation Sole.”; Maitland, "Crown as Corporation."
} 
"apparatus is the mechanism by means of which the person comes into view." 104 As an extension of the symbolica heroica, which places the individual within a visual legal ordering, the person functions as an 'optical apparatus' that brings the individual before the law, making them both visible and, by doing so, governable. Alciato himself, as Goodrich notes, defined "man' "as legis imago...the image of law, or, just as plausibly, a legal actor." 105 A legal actor that is presented to the law, but is also created and recognised by the law, and which the law must see in order to govern. ${ }^{106}$

In this context, the aspect of the confrontation clause jurisprudence that the comics did not raise is important - the ability for the judge and jury to observe the demeanour of the witness so as to judge their credibility, through an apprehension of their appearance and by looking them in the eyes as they respond to cross-examination. In the emblem tradition, the absence of the eyes or, later, the blindfold reflected not only that there is to be no influence "by circumstances, affinities, or affections" but also that the result of not being able to see means that "external rhetoric, gesture, and gesticulation...are irrelevant." 107 While the formal 'blindness' of modern law desires to ignore the body, to "remain studiously oblivious to the art and artifacts, the context and style of judgment and other juridical performances," what is retained in the requirement of confrontation is a concern with the performance of law itself - the ritualistic and theatrical presentation of the trial that is required to take place in vivo. ${ }^{108}$ The concern with anonymous testimony, or the wearing of a disguise in court, goes, in part, to the inability of the observer to then be able to judge the demeanour of the witness and, by extension, (supposedly) their credibility. Daredevil's testifying while wearing a mask not only maintains the anonymity of his secret identity and encompasses the performance of his public persona, but also hides his demeanour. The visors that not only hide his eyes but also his blindness prevent the ability of the judge and jury to observe and judge his testimony. What is presented instead is a physical rhetoric of bodily performance — one which, as we will now see, includes both a literal and figurative transformation and re-signification of the courtroom as the realm of visible law.

\section{Re-Signifying the Law: Soule's Juridical Visual Economy}

As noted in Section 2 above, Manderson argues that what is significant about the functioning of images is not so much the way in which images change to reflect different times and meanings, but that the same image, the same signifier, can represent different or changing signifieds. ${ }^{109}$ Soule's run on Daredevil involves an explicit playing with the traditional visual representations of law, a critical exploration and re-signifying of our legal emblems. The conclusion of the first issue of 'Supreme', which has provided the background of Murdock's bringing of the legal case, encompasses the opening images of the trial scene discussed above. ${ }^{110}$ In five panels, the viewer is presented with the traditional visual cues of the courtroom (see Figure 5): a full gallery with a traditional wooden barrier; a judge in black robes at his bench set on high with part of an American flag behind him; an indistinct image of the empanelled jury, with the court artists in front, engaging in the process of 'drawing the human' on the stand. In each of the panels, these images are set behind a court bailiff who is providing the instruction and iconic words of the oath: "Do you solemnly swear to tell the truth...the whole truth...and nothing but the truth...so help you God?" The concluding full-page image of the issue then reveals Daredevil in the witness stand, with his right hand raised saying "I do" (see Figure 6).

\footnotetext{
104 Goodrich, "Theatre of Emblems," 56.

${ }^{105}$ Goodrich, "Theatre of Emblems," 58.

106 Goodrich, "Theatre of Emblems," 56.

${ }^{107}$ Goodrich, Legal Emblems, 168.

108 Goodrich, Legal Emblems, 167. It is significant to note that during the writing of this piece, this requirement has been altered in various ways in response to COVID-19 shutdowns around the world, with court procedures being conducted virtually more and more often.

109 See also Manderson, "Trench, Trail, Screen," 140-142.

110 Soule, "Daredevil \#21 'Supreme' Part 1."
} 

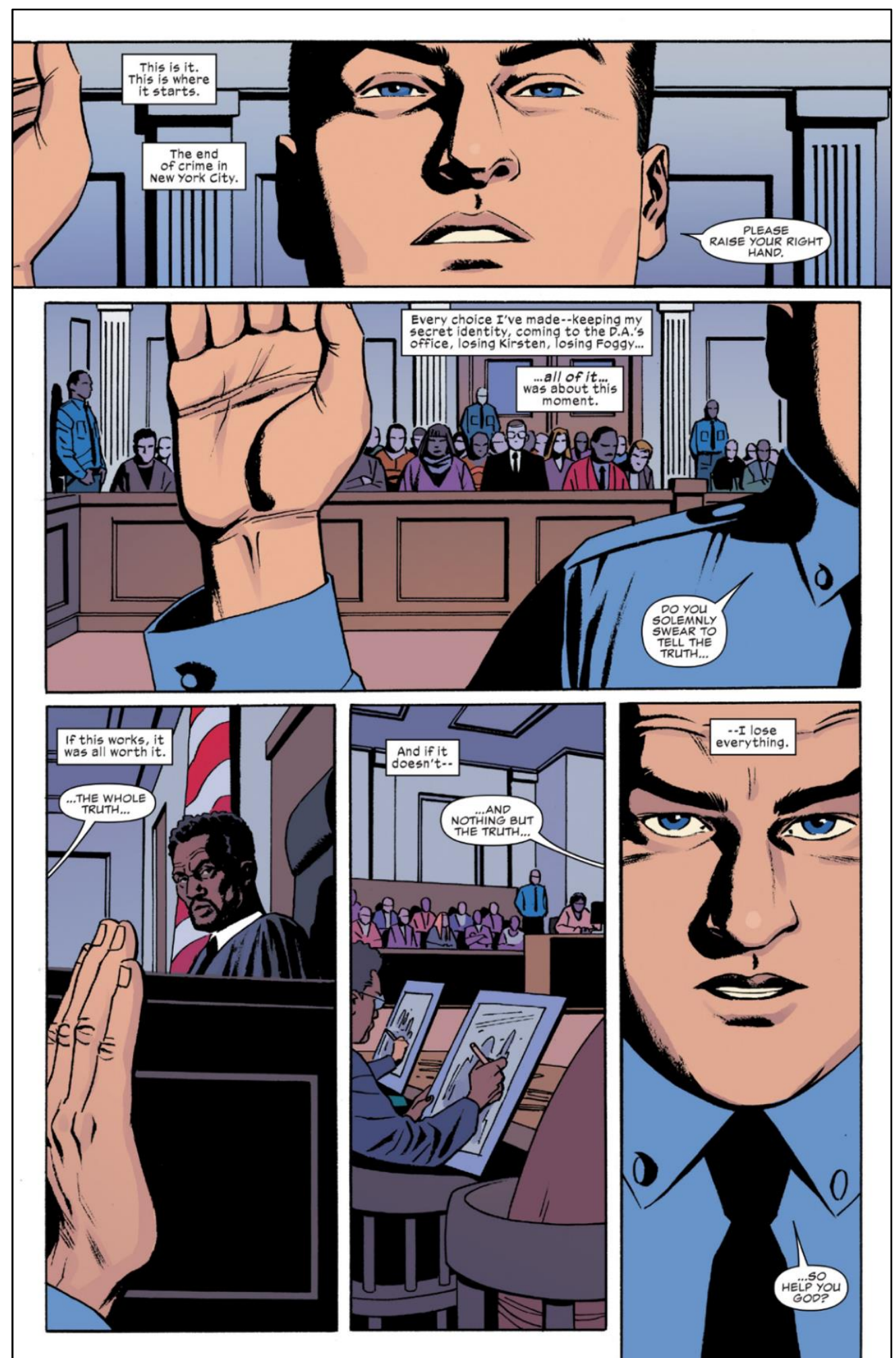

Figure 5. Panel from Soule's Daredevil: Back in Black Vol. 5: Supreme \#21, 2017.

Image Credit: Goran Sudžuka (C) 2017 Marvel Characters, Inc 
What is significant here is the way in which the comics form functions to reproduce the iconic visual tropes of the courtroom, thus setting-up the viewer to 'see in' the images the authority of what the judge describes in the next issue as the august space of law, a "fortress of civilisation." 111 The concluding words of the issue, however, are an internal monologue that finishes with an assertion of identity: "I am Daredevil. I am not afraid." 112

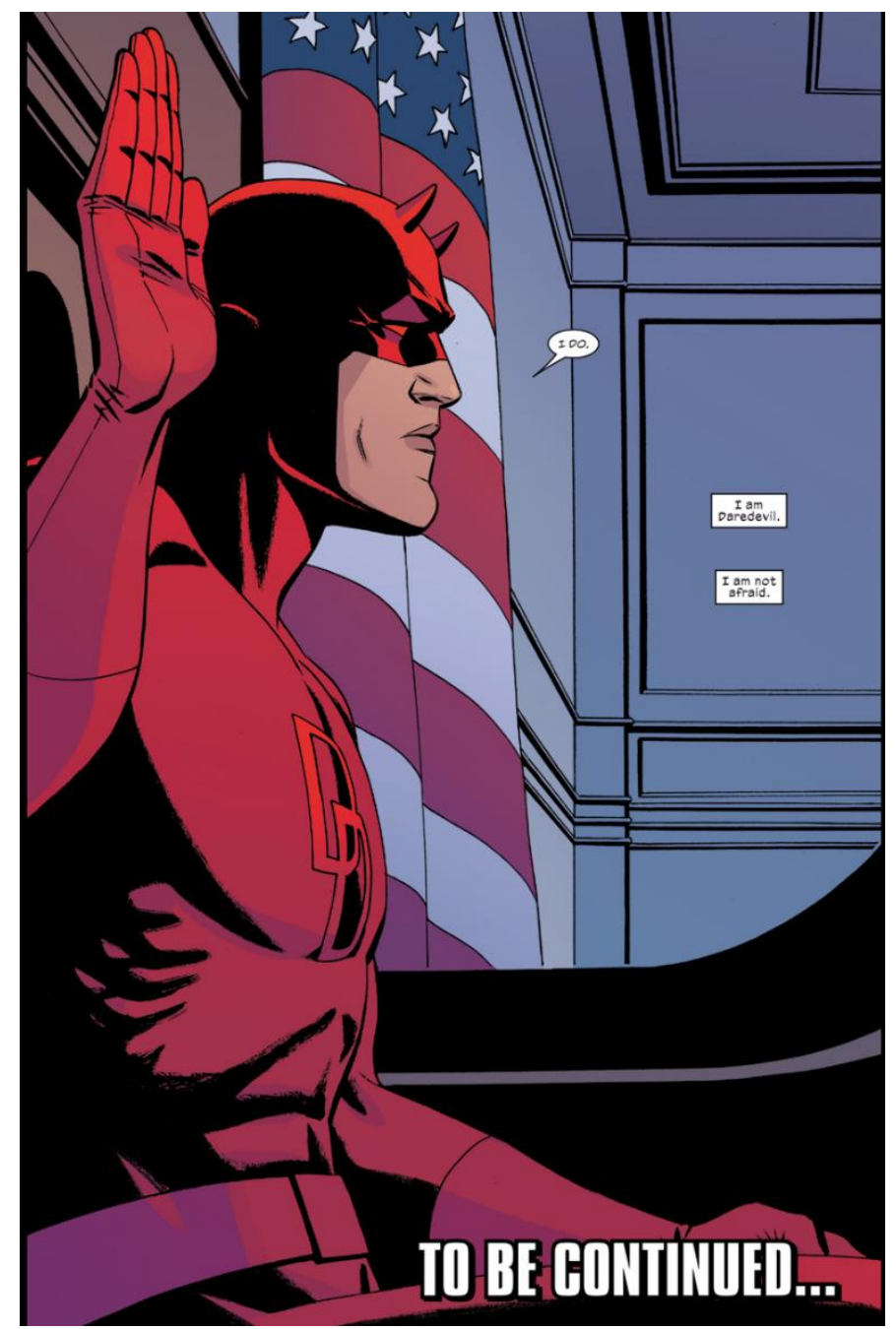

Figure 6. Page from Soule's Daredevil: Back in Black Vol. 5: Supreme \#21, 2017.

Image Credit: Goran Sudžuka (C) 2017 Marvel Characters, Inc

The opening panel of the next issue (see Figure 7) picks up directly where the previous one left off, with a close-up of two brown eyes on a black face, intent and focused saying "the courtroom is a sacred place."113 The intensity of these panels focuses on the judge's outlining of the significance of both the courtroom and the office of the judge:

In this place, things that are wrong can be put right. This is my opinion, of course. However, it is a powerful opinion, vested with the authority of the state of New York. With this mind, I consider the great questions. With this hammer I mete out justice. And from this bench, I rule [all emphases in original]. ${ }^{114}$

\footnotetext{
111 Soule, "Daredevil \#22 'Supreme' Part 2."

112 Soule, "Daredevil \#21 'Supreme' Part 1."

${ }^{113}$ Soule, "Daredevil \#22 'Supreme' Part 2."

${ }^{114}$ Soule, "Daredevil \#22 'Supreme' Part 2."
} 


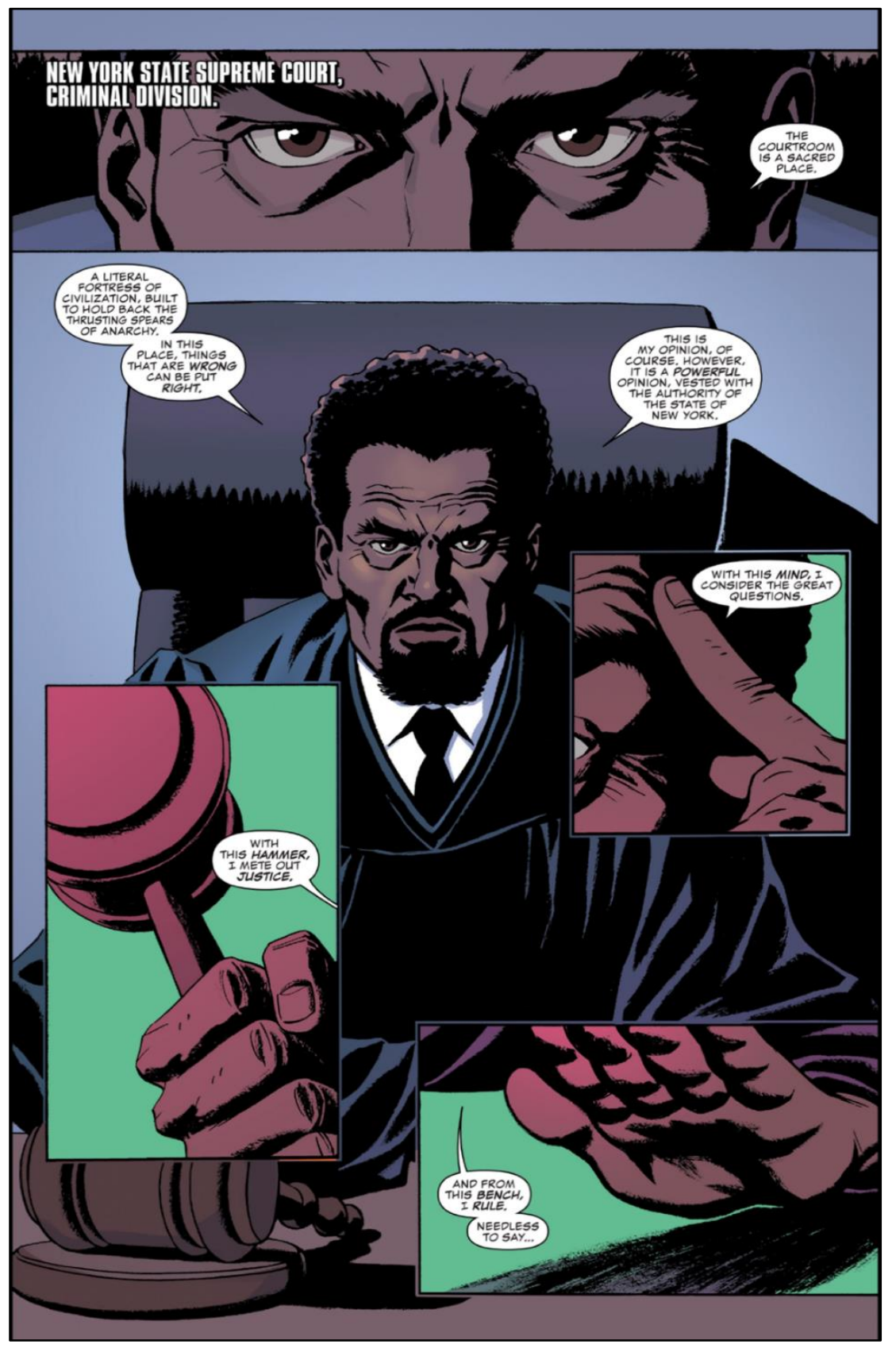

Figure 7. Page from Soule's Daredevil: Back in Black Vol. 5: Supreme \#22, 2017.

Image Credit: Goran Sudžuka (C) 2017 Marvel Characters, Inc

All this rhetorical presentation of the imagery of law and justice, noting the significance of the physical space of the courtroom, along with its symbolic trappings (the hammer or gavel, and judge positioned on high behind his bench, ruling over his courtroom) undergirding the authority vested in his opinion, the authorised office of the judge, essentially leads to his statement: "... I'm not a big fan of stunts [emphasis in original]." At this point, the shift is from a close-up to the full courtroom, with Daredevil, partially obscured, in the witness stand (see Figure 8). In the two-page spread that goes through aspects of the case and whether Daredevil understands its implications, Daredevil is presented as physically below the judge, often small and positioned in the right-hand lower corner. Instead of the larger-than-life presentation of the superhero, he is positioned within and subordinate to the august space of law. 


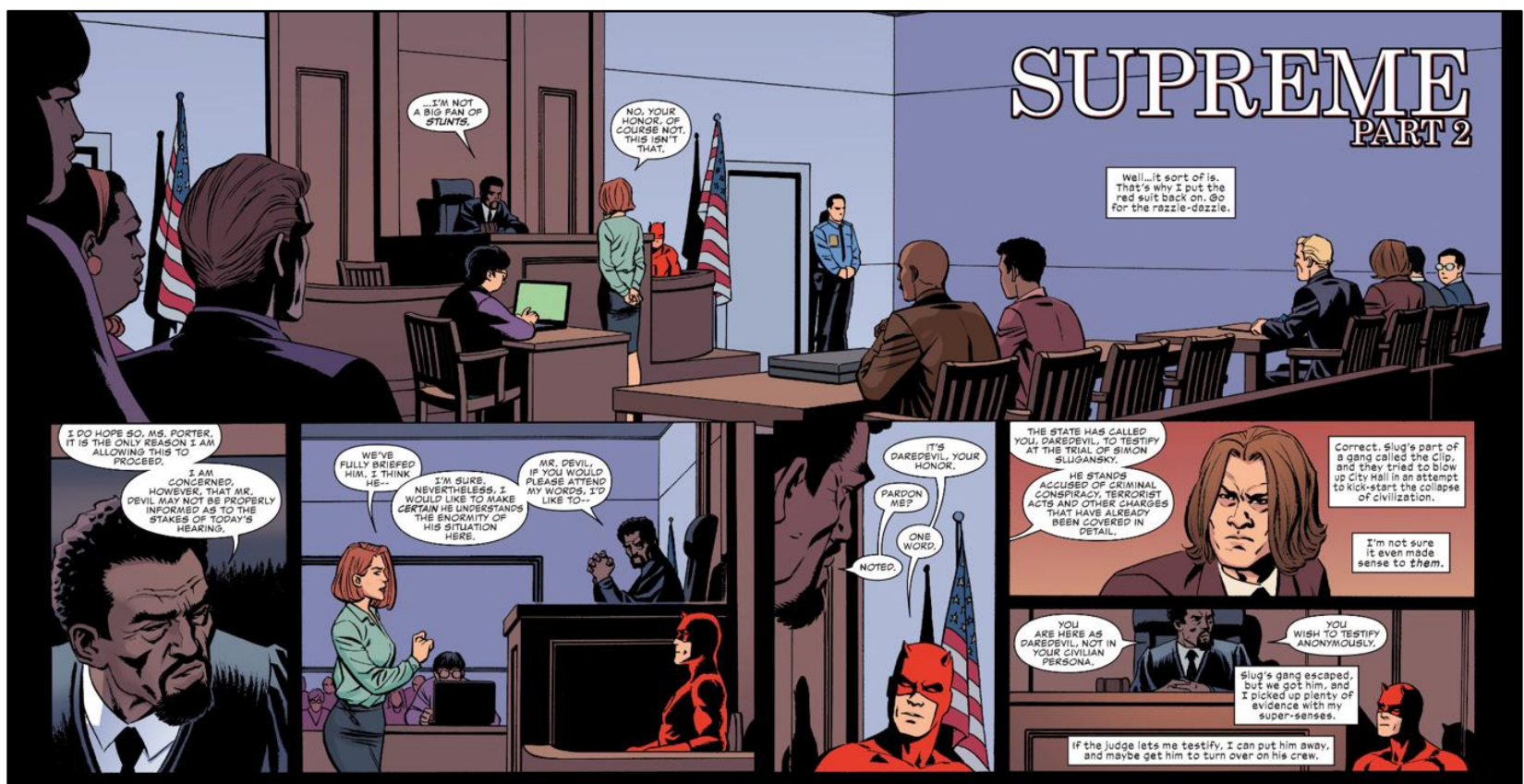

Figure 8. Page from Soule’s Daredevil: Back in Black Vol. 5: Supreme \#22, 2017.

Image Credit: Goran Sudžuka (C) 2017 Marvel Characters, Inc

As defence attorney Baden is questioning the witness to determine whether there is any proof that he is in fact Daredevil, this august space of law, however, is transformed. Daredevil is being questioned on his super-senses when his radar sense picks up the rest of the defendant Slug's crew walking into the building. They burst into the courtroom shooting, and Daredevil dives to push the defence attorney out of the way (see Figure 9). 


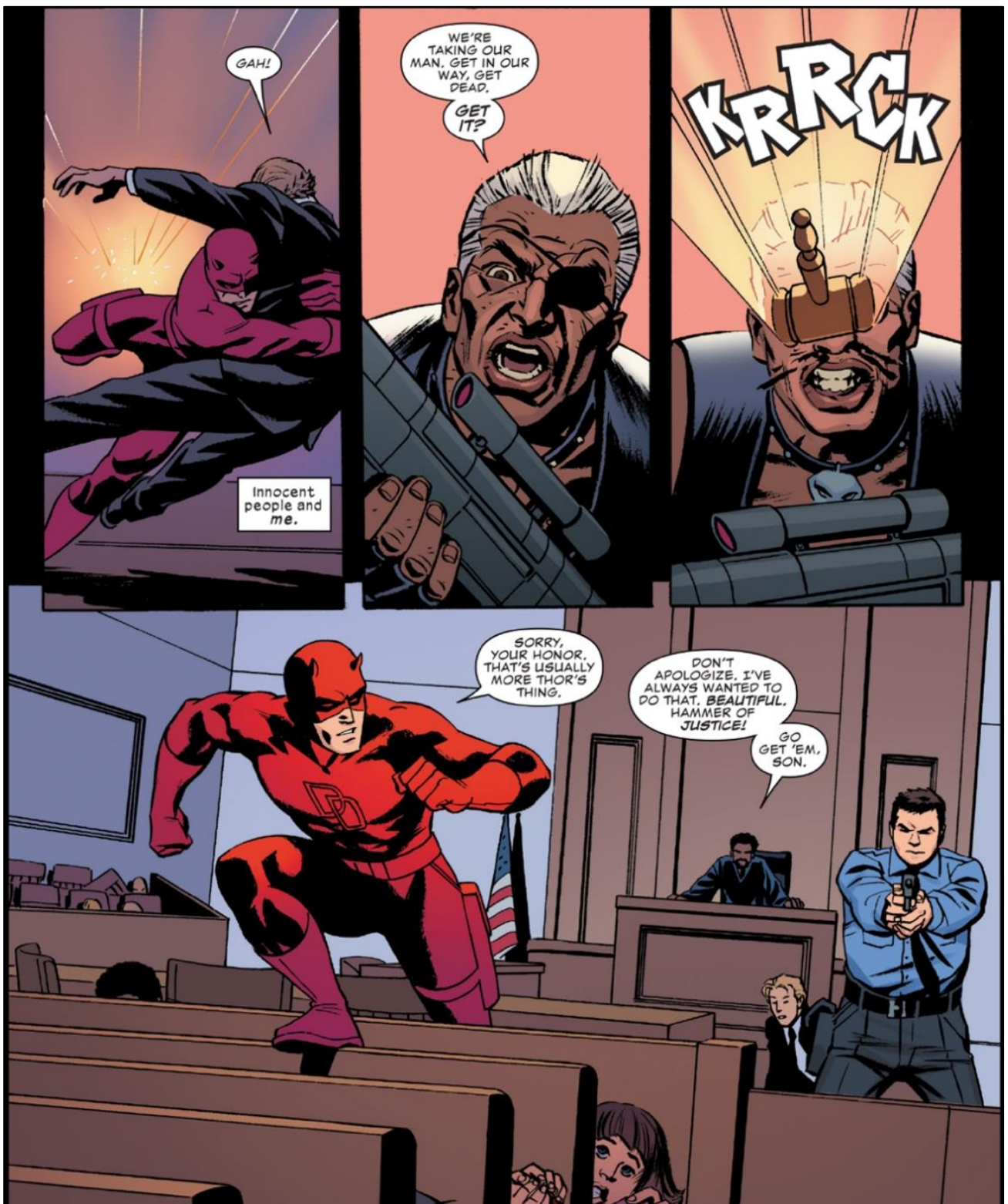

Figure 9. Page from Soule's Daredevil: Back in Black Vol. 5: Supreme \#22, 2017

Image Credit: Goran Sudžuka (C) 2017 Marvel Characters, Inc

The crew leader then shouts "We're taking our man. Get in our way, get dead. Get it?" This instruction, with all its cliché grammatical infelicities, is cut short by a flying gavel to the nose, with a nice superhero sound-effect: "KRRCK!" Daredevil, while climbing over seats to get to Slug's crew, says flippantly to the judge "Sorry, Your Honor. That's usually more Thor's thing." 115 To which the judge, who having proclaimed the solemnity and formality of the court and his disinclination towards stunts, now says "Don't apologize. I've always wanted to do that. Beautiful. Hammer of justice! Go get 'em, son [all emphases in original]." 116 Visually, here, Daredevil now replaces the judge in the front and top left of the panel, situated above him. That is, as Daredevil goes to attack the bad guys, he disrupts the visual structure and authority of the court—using the gavel literally

115 Soule, "Daredevil \#22 'Supreme' Part 2." While such is obviously a direct reference to the superhero, Thor, it also resonates with the claimed genealogical link that traces the contemporary gavel as a symbol of authority to its use by Freemasons, before that to the constitution of Gothic courts and then as far back as Norse mythology and Thor's Miölner. See Fort, Early History and Antiquities of Freemasonry, 274280. See discussion in Parker, "Gavel," 220-221.

116 Soule, "Daredevil \#22 'Supreme' Part 2." 
as a weapon, rather than its institutional capacity as an emblem of authority. Such a re-signification, however, is one that is implicit in the symbolism of the gavel itself - it having made its way into American courts through Freemasonry, which, while taking on its own iconologia, also encompassed its role as both tool and weapon. As James Parker has noted, this capacity of the hammer as weapon "speaks equally of law's enforceability, its capacity for and dependence on violence. As a technique and icon of authority, the gavel has more in common with Justitia's sword than her scales." ${ }^{117}$ In Daredevil's use, the visual iconicity of the hammer or gavel is re-signified, returned to its mundane rather than institutional use. In the same move, the role between the superhero as a particular embodied persona of justice, as opposed to the judge as the embodiment of an office invested with authority, is inverted.

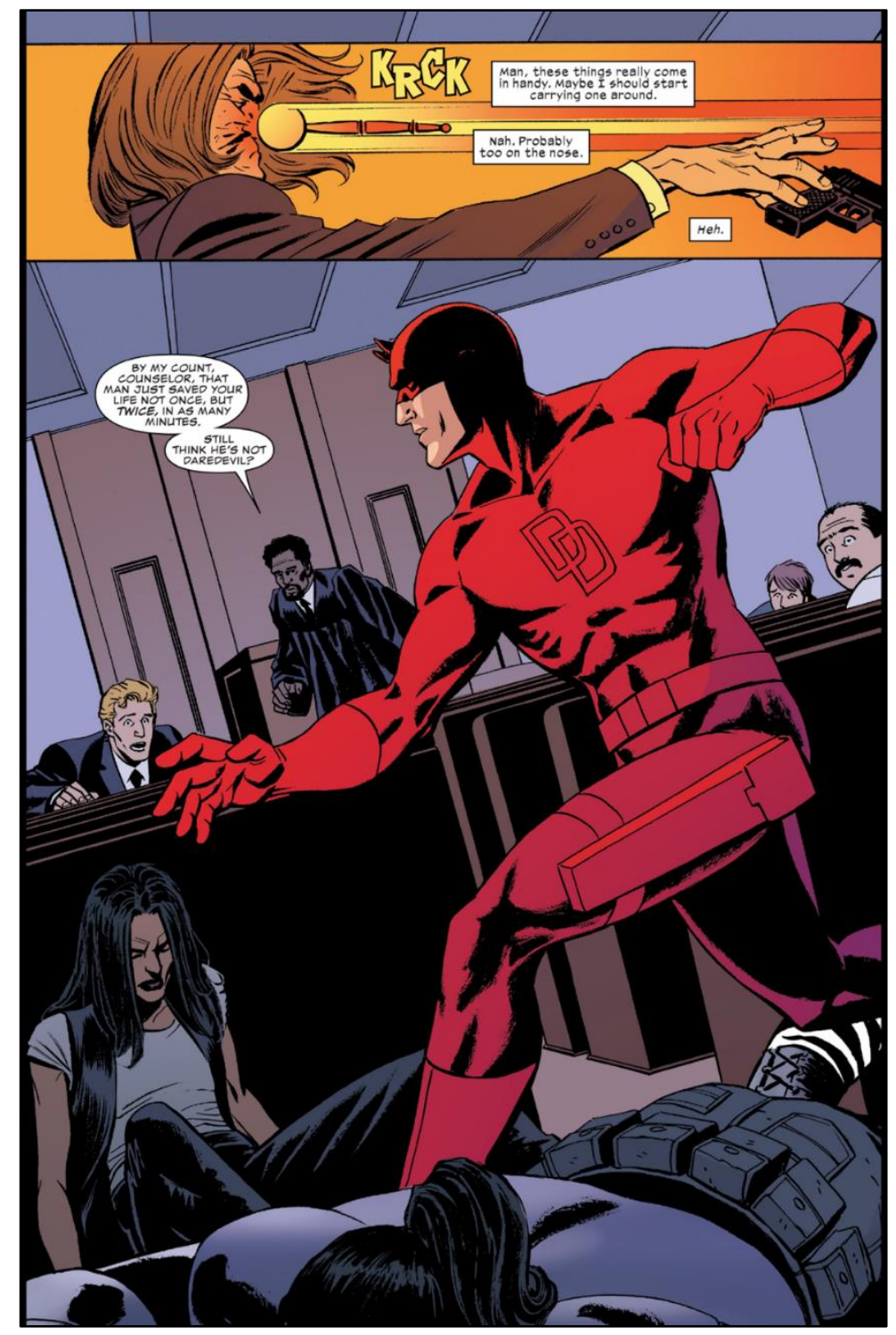

Figure 10. Page from Soule's Daredevil: Back in Black Vol. 5: Supreme \#22, 2017.

Image Credit: Goran Sudžuka @ 2017 Marvel Characters, Inc

The conclusion of this brief fight scene has Daredevil positioned in an athletic pose, fist drawn back for one last punch, musculature clear through his suit, and DD insignia front and centre, thus emphasising the identity of Daredevil (see Figure 10) — a point that the judge then raises with the defence counsellor, noting that his life had been saved twice: "still think he's not Daredevil?" Picking the gavel up off the floor and handing it back to the judge, he notes "I'm good." At this point, the judge

117 Parker, "Gavel," 221. 
calls for the courtroom to be put back in order so that the case can continue - with a final "RAP" from the gavel now returned to its authorised bearer and institutional use (see Figure 11). The formality of the courtroom and the law, which struggles with the possibility of being deceived by the 'persona' of the superhero's mask and suit that may hide any particular 'body', is transformed when the gang breaks in to a trial by battle and of images. In doing so, however, the threshold remains crossed, the court remains 'in session' and the battle, thus, forms part of the trial, with the efficacy of Daredevil's 'performance' satisfying the court of his own symbolic identity.



Figure 11. Panel from Soule's Daredevil: Back in Black Vol. 5: Supreme \#22, 2017.

Image Credit: Goran Sudžuka (C) 2017 Marvel Characters, Inc

This playing with the visual iconicity of the courtroom reappears in the later issue of 'Supreme', when Murdock is presenting submissions to the US Supreme Court. ${ }^{118}$ As the scene moves to Matt about to present his submissions, we once again see the grandeur and solemnity of the court - the height of the justices, the lowly position of those presenting submissions before them, the architectural ornaments and art of the Supreme Court itself (see Figure 12). The muted tones of the panel are then thrown into sharp relief just after Matt begins his submissions - with an image of a gavel punching him in the face (once again with an accompanying "KRRCK"; see Figure 13). This time, it is not thrown by Daredevil who had appropriated the emblem of authority from the judge, but by one of the US Justices themselves - each of whom now engage in a stylised fist fight with Murdock, complete with surrealist patterns and colours in the background. In this sense, the law itself is presented as a trial by battle, not so much about justice being the outcome of the process but justice being the outcome of the battle between the lawyers and judges. Visually we have, once again, a specific re-signification of the court proceedings. If we focus on the gavel in particular across the depictions of the two trials, it shifts from its institutional symbolism of authority in the hands of the trial judge, to a literal deployment as a weapon by Daredevil, to a presentation of a metaphorical image of justice as the dealing of violence. Furthermore, instead of the courtroom being 'invaded' and dominated by a battle, which afterwards is taken as proof or evidence of the matter in question in court, what is revealed here is the way in which the court always is such a dealing of violence - not simply a war of words, legal reasoning and argument, but, as Robert Cover noted, a form of interpretation that "takes place in a field of pain and death."119

\footnotetext{
${ }^{118}$ Soule, "Daredevil \#25 'Supreme' Conclusion."

${ }^{119}$ Cover, "Violence and the Word," 1601.
} 


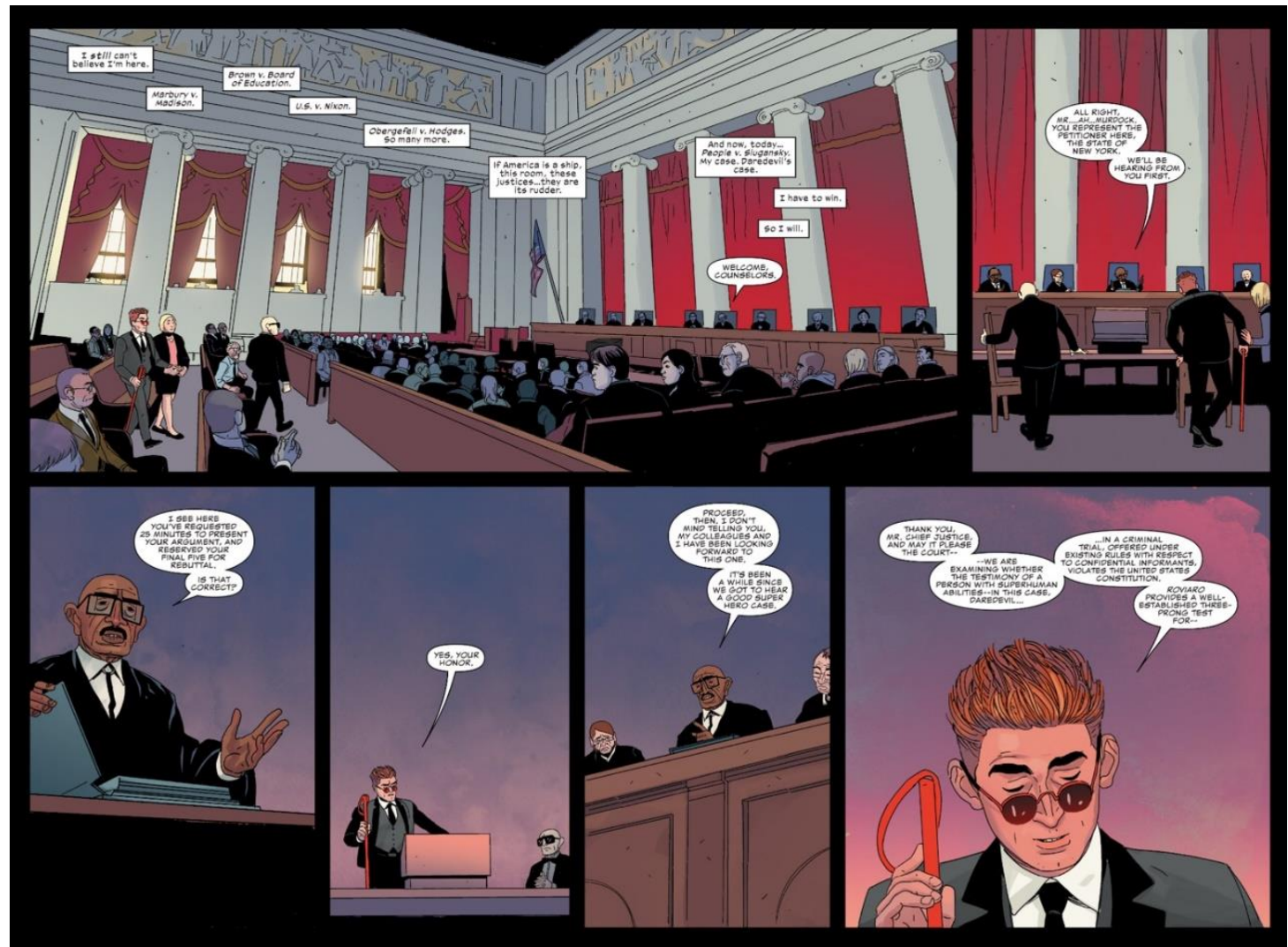

Figure 12. Panel from Soule's Daredevil: Back in Black Vol. 5: Supreme \#25, 2017.

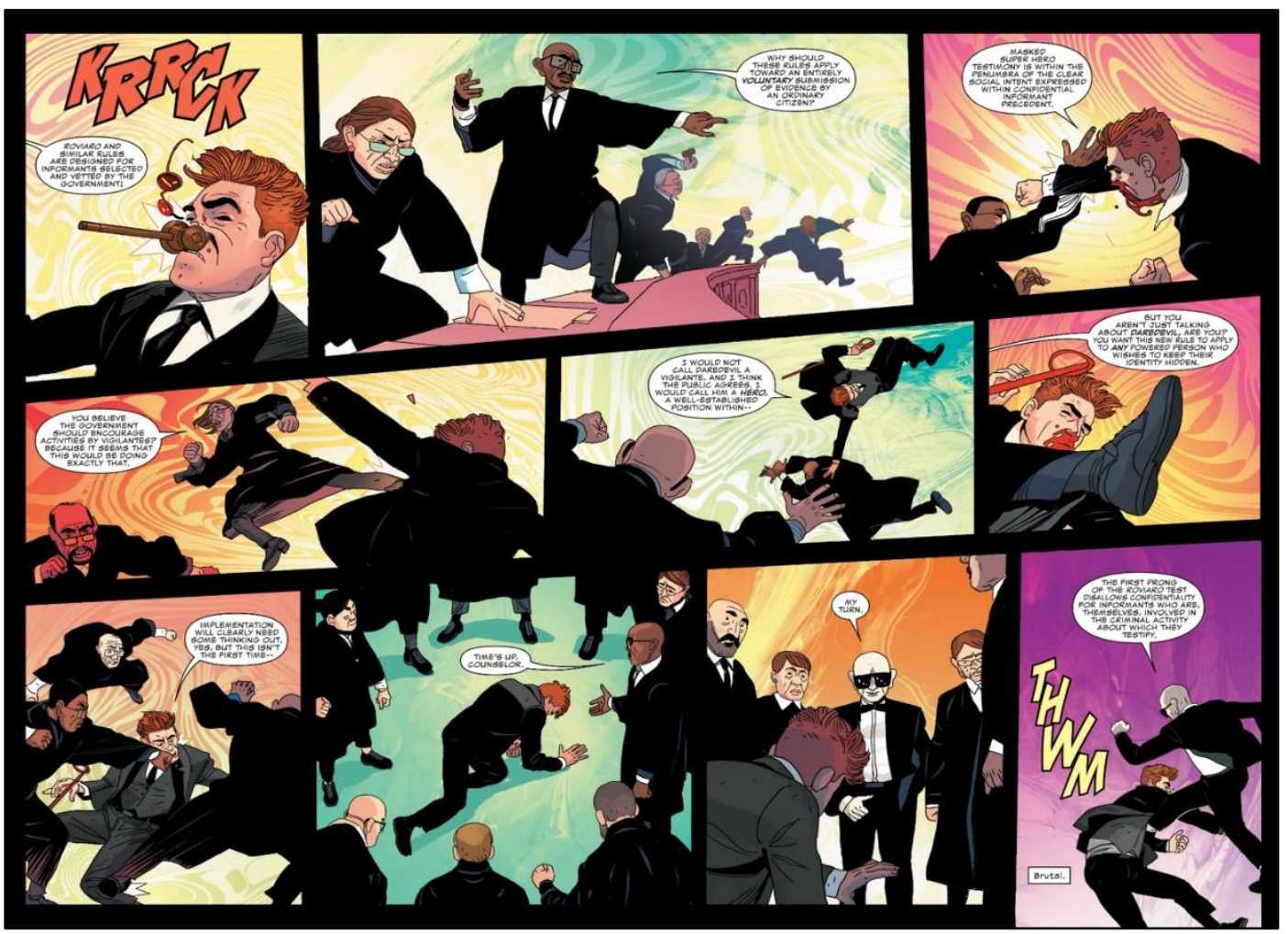

Figure 13. Page from Soule’s Daredevil: Back in Black Vol. 5: Supreme \#25, 2017.

Image Credit (Figures 12, 13): Alec Morgan @ 2017 Marvel Characters, Inc 
It is with this association of the court with its violence that we find the significance of the emblematic reading of Daredevil's two personas that are here inverted by Soule. The issue opens with Matt and his partner Foggy outside the Supreme Court building itself expressing the appropriate notes of awe. ${ }^{120}$ However, while we have presented here the architectural grandeur of the courthouse, in Matt's discussion with Foggy he also notes the institutional significance of the Court and the importance of a lawyer appearing before it:

How much power does any one lawyer really have? Most of the time, we work with a single client. We can help them, but in
terms of our impact on the world...it's a one-at-a-time thing. Incremental. But here...if you can get the Supreme Court to
decide in your favour, their ruling becomes the rule. Here, with wit, words and will, an attorney can create meaningful change
for the entire country. Here, a lawyer's ordinary power is amplified a thousand times. Here, a lawyer becomes a superhero. ${ }^{121}$

Visually, most of these words are presented not as speech bubbles - the visual presence of an absent speaker-but as squares over or in front of the image of the Supreme Court with all its visual iconography (see Figure 14). The graphic positioning of this text in the comic, thus, takes the same form as the words 'equal justice under law' do on the frontage of the courthouse. These words that are an embodiment of a particular national understanding of law, and of the rule of law, are themselves part of the image - a presentation of the nature of law. These words themselves encompass the opposite of the superhero critique of the law and rather are a defence and support of a legal system built upon the law. Murdock's narrative, however, takes the idea of the 'heroic lawyer' to the extreme by presenting the lawyer as a superhero-even if, in doing so, he is arguing for a limitation upon the very rights that justice and equality under law would seem to protect. ${ }^{122}$

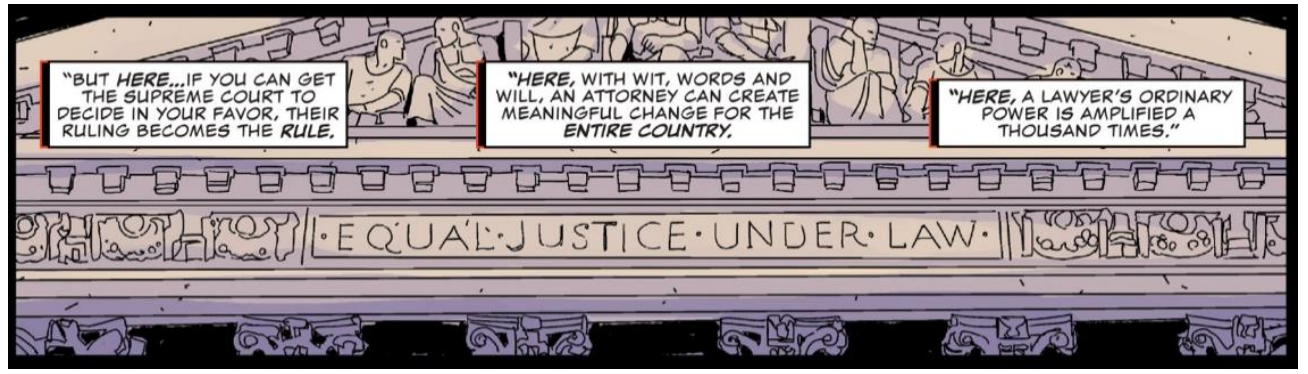

Figure 14. Panel from Soule's Daredevil: Back in Black Vol. 5: Supreme \#25, 2017.

Image Credit: Alec Morgan (C 2017 Marvel Characters, Inc

If, in this process, Matt Murdock as blind lawyer becomes the superhero (as opposed to his alter-ego Daredevil), then, in true fashion, there is also a villain for Matt to fight: the attorney hired by Wilson Fisk known simply by the name 'Legal'. It is through the interactions with this character that the critical and satirical nature of Soule's run is drawn out. Legal is introduced to the reader in an interview with Fisk who presents an exemplary legal realist understanding of the law, positioning himself as Oliver Wendell Holmes' 'bad man' ${ }^{123}$ :

\begin{abstract}
I know the law...I have to. As much as any lawyer, any cop. It's part of the work. The law is just a bunch of boundary lines. Marks off territory. Theirs... and mine. I know where I can go, and where they can go. They use it, and so do I [all emphases in original]. ${ }^{124}$
\end{abstract}

Fisk encompasses a morally neutral view of the law, a particular understanding of it as delimitating what can and cannot be done within its remit, the consequences of its contravention and, more specifically, what can and cannot be proved. Such reflects the methodological position that Holmes' argued is the basis for understanding the law.

Legal, however, challenges Fisk's view. After Legal wins the case before the New York Court of Appeals, Fisk notes that "the law was on my side, for once," to which Legal responds that "[ $\mathrm{t}] \mathrm{he}$ law is on no one's side. It can be used to support any position if the attorney making the relevant arguments is sufficiently skilled. The law is an abstraction. A tool. Nay, an instrument

\footnotetext{
120 Soule, "Daredevil \#25 'Supreme' Conclusion."

121 Soule, "Daredevil \#25 'Supreme' Conclusion."

${ }^{122}$ For a discussion of the "heroic lawyer' in popular culture see: Asimow, "When Lawyers Were Heroes."; Bainbridge, "Lawyers, Justice and the State.”; Kamir, "Anatomy of Hollywood's Hero-Lawyer."; Kamir, "Michael Clayton: Hollywood's Contemporary Hero-Lawyer."

${ }^{123}$ Holmes, "Path of the Law."

124 Soule, "Daredevil \#23 'Supreme' Part 3.”
} 
[emphasis in original] to be played." ${ }^{25}$ He describes both himself and Murdock as 'virtuosos' and that the Court of Appeals "simply enjoyed my tune more than his." ${ }^{126}$ Later on, in conversation with Murdock, he describes all courts as necessary fictions and the law as a 'secret language': "The more fluently you speak it, the more easily humanity's social constructs bend to your will. From speeding tickets to national elections - if you speak the law, the world is what you want it to be. Lawyers are magicians." 127

Whereas Fisk views the law in simply instrumental terms, something that is known by the 'bad man', and for which they can calculate the consequence of transgression, for Legal, the law is an instrument itself, a means of manipulating social constructions for particular outcomes:

The law is not absolute and it is not applied equally. That idea is another necessary fiction. The variable in that uneven application - the single factor that determines whether a guilty man goes free or spends his life in prison—is the lawyer. ${ }^{128}$

While Legal is set up as the villainous counterpart - and in the Supreme Court scene he also fights Matt with an argument presented as a literal kick in the guts (see Figure 13) - his vision of legality aligns with Murdock's own. For the obverse side of the argument that a lawyer who gets a ruling in the Supreme Court and, thus, enables "meaningful change for the entire country" is a superhero, is the emphasis on the individual capacity of the lawyer. This is not a vision of law as an enterprise that is essentially bound to life, community or justice, but an abstracted technology that can be controlled, manipulated and deployed for particular ends. This goes beyond the self-interested ends of the criminal, to a manipulation of the very fictionality of law as an esoteric and magical language - the enigmas of law captured by the emblem tradition-that supposedly provides the ability to control the construction of the world. Law here bears no relationship to justice but is rather simply a means to an end ${ }^{129}$ — valid, but without significance. ${ }^{130}$ In this sense, despite attempting to present a 'legitimate' and legal role for the superhero, the image Soule presents is one of a further transformation of the law, justifying both the vigilante justice of the superhero and the limitation of the fundamental right to a fair trial. The exceptional status of the superhero is made indistinct with the law itself. ${ }^{131}$

\section{Conclusion: The Lawyer as Superhero, or What Becomes of the Rule of Law?}

Sherwin's examination of what authorises the image, of the "source of law's legitimacy in the 'visiocracy' that we call home," is situated within a desire for a stabilisation of the relationship between law and justice in our modern visual economy. ${ }^{132}$ The artistic endeavour is critical to this need for stabilisation, to see law "less as a metric system" and rather like "a musical performance" or a "work of art", a "public performance" rather than "a passive archive of written rules, policies, and principles" - "a theatre in which we perform a shared reality, clearing a space — an oikos — for reality to appear." 133 This is a turn from an epistemology that measures visual economy in terms of its accuracy to a post-secular recapturing of an earlier theological and humanities-based authorisation of knowledge - an economy of the sublime, seeing the image as appearance, performance and event. Such is to reimagine law as a "visual economy, a matter of embodied seeing" in which:

[T] hose legal institutions that establish and maintain basic concepts (such as due process, equal protection, liberty for all) also help express and perform a preferential range of shared emotions. Where everyone recognizes that structures of feelings help to create individual identity as well as social reality, and in which legal institutions help us to avoid 'bad civic passions' (such as fear, envy, and shame) while promoting the good (compassion, respect, perhaps even love). ${ }^{134}$

Such is the task of a modern legal humanism.

At one level Soule's emblematic presentation of Daredevil would appear to fit with this vision of post-secular legal humanismreflecting the original figure of blind justice as satirical critique, rather than positive emblem. Like Brant and Dürer's critique of the emergence of modern legality and a legal profession trained in interpretation and legal technicality but lacking the virtue

\footnotetext{
125 Soule, "Daredevil \#24 'Supreme' Part 4."

126 Soule, "Daredevil \#24 'Supreme' Part 4."

127 Soule, "Daredevil \#25 'Supreme' Conclusion."

128 Soule, "Daredevil \#25 'Supreme' Conclusion."

129 Tamanaha, Law as a Means to an End; Berkowitz, "From Justice to Justification."

130 Sherwin, "What Authorizes the Image," 142.

${ }^{131}$ My allusion here is, of course, to Agamben, State of Exception.

132 Sherwin, "What Authorizes the Image," 333; Goodrich, Legal Emblems, 16; Mondzain, Image, Icon, Economy, 152.

133 Sherwin, "What Authorizes the Image," 334.

134 Sherwin, "What Authorizes the Image," 334.
} 
needed to accompany it, Soule reflects a similar humanistic critique of law. ${ }^{135}$ In the humanising tradition of law and literature, he presents a model of the 'heroic lawyer', upholding an ethical commitment to using the law to change the world and do what is right. This is the vision of lawyer as superhero, deploying their 'legal superpowers' for good and not for evil. As Murdock states, "As Daredevil, I get to save the world. As a lawyer ... maybe I can fix it."136

However, while the reader is positioned to view Murdock as a lawyer-superhero, it is the character Legal, positioned as villain, that uses the musical metaphor that Sherwin invokes. That is, the lawyer's superpower can be put to multiple ends, both moral and immoral, within a vision of law that is not connected to any inherent goodness or a commitment to the rule of law, but seen as an instrument to be played. Lawyers are virtuosos, magicians who bend the world to what they want it to be. ${ }^{137}$ These include villainous ends, not just in terms of Legal supporting a criminal mastermind such as Wilson Fisk, but also in terms of Murdock getting the Supreme Court to rule that the fundamental rights of the modern legal trial, the right for an accused to know and be confronted by their accuser, be limited. That this position is presented as heroic, in itself, reflects the way in which the lawyercum-superhero is functioning as a transitional myth - an enabling of an exceptionalised view of legality that has become the norm, a deployment of the rule of law not to limit the abuse of state power but to extend it. The key to understanding the emblematic nature of Soule's narrative and its satirical account of the law is, thus, not through the character who declares "I am Daredevil" but the one who explicitly says "as in all things, I am legal."138

\section{Acknowledgements}

Early versions of this article were presented at a seminar co-hosted by the Dundee Law School, the Centre for Creative and Critical Cultures and the Scottish Centre for Comics Studies, as well as the 2019 Graphic Justice Discussions Conference 'Drawing the Human: Law, Comics, Justice', hosted by the School of Law and Criminology, University of the Sunshine Coast. Many thanks to the hosts (Thomas Giddens, Dale Mitchell and Ashley Pearson), attendees and participants at those events, and for the critical conversations that emerged out of them, in particular with Thomas Giddens, Sonja Schillings and Chantelle Peters. Thanks also to the anonymous reviewers for their useful feedback and critical comments on the paper; to Kieran Tranter for his editorial patience and prowess; and to Michaella Duggan for her excellent research assistance in finalising the article. All errors remain my own.

\footnotetext{
${ }^{135}$ In July 2018, in the context of news coverage of Michael Cohen's (former lawyer to Donald Trump) lawerly infelicities, Charles Soule tweeted the following: "Knowing the law can be a superpower. Attorneys understand society's infrastructure and how to manipulate it.... Lawyers are magicians, in a very specific, boring, but incredibly powerful way. But, of course, power can be abused. And if you're not careful, you end up a supervillain. Some attorneys believe that because they understand the law, they're above it, or they can abuse it and never get caught. Some pass that belief on to their clients, who then hire them not to do what lawyers swear an oath to do- uphold the lawbut to break it ... Fortunately, there's another kind. Some-no, most-lawyers care about their clients, put them above themselves, do everything they can to use their knowledge of the law to help them, or society as a whole." Quoted in Rosen, "Lawyer as Superhero," 429430.

136 Soule, "Daredevil \#25 'Supreme' Conclusion."

${ }^{137}$ It is also significant that in an earlier narrative arc, Daredevil fights the villain Muse — an artist who literally makes art through an act of killing and positioning the embodied (super)human. See Soule, Daredevil: Back in Black Vol. 3.

138 Soule, "Daredevil \#23 'Supreme' Part 3."
} 


\section{Bibliography}

\section{Primary Legal Sources}

Detective Comics Inc v. Bruns Publications Inc, 111 F.2d 432 (2nd Cir. 1940).

Jarvie v. Magistrates' Court of Victoria [1995] 1 VR 84.

Roviaro v. United States, 353 U.S. 53, 60-61 (1957).

\section{Primary Cultural Sources}

Hine, David and Michael Gaydos. Daredevil: Redemption. New York: Marvel, 2005.

Lee, Stan, Bill Everett and Sam Rosen. "Daredevil \#1: The Origin of Daredevil." In Daredevil Epic Collection: The Man Without Fear, edited by Stan Lee, Dennis O’Neil and Wallace Wood. New York: Marvel, 1964.

Millar, Mark and Steven McNiven. Civil War: A Marvel Comics Event. New York: Marvel, 2007.

Miller, Frank, Klaus Janson and Lynn Varley. Batman: The Dark Knight Returns. New York: DC Comics, 1986.

Miller, Frank and John Romita, Jr. Daredevil: The Man Without Fear. New York: Marvel, 1993.

Soule, Charles, Matteo Buffagni, Vanesa R. Del Ray and Goran Sudžuka. Daredevil: Back in Black Vol. 2: Supersonic. New York: Marvel, 2016.

Soule, Charles, Christos N. Gage, Ron Garney and Stefano Landini. Daredevil: Back in Black Vol. 6: Mayor Fisk. New York: Marvel, 2018.

Soule, Charles and Ron Garney. Daredevil: Back in Black Vol. 1: Chinatown. New York: Marvel, 2016.

- Daredevil: Back in Black Vol. 3: Dark Art. New York: Marvel, 2017.

Soule, Charles, Ron Garney, Dan Panosian and Goran Sudžuka. Daredevil: Back in Black Vol. 4: Identity. New York: Marvel, 2017.

Soule, Charles and Mike Henderson. Daredevil: Back in Black Vol. 7: Mayor Murdock. New York: Marvel, 2018.

Soule, Charles and Alec Morgan. “Daredevil \#23 'Supreme’ Part 3.” In Daredevil: Back in Black Vol. 5: Supreme. New York: Marvel, 2017.

_ . "Daredevil \#25 'Supreme' Conclusion.” In Daredevil: Back in Black Vol. 5: Supreme. New York: Marvel, 2017.

Soule, Charles and Phil Noto. Daredevil: Back in Black Vol. 8: Death of Daredevil. New York: Marvel, 2019.

Soule, Charles and Goran Sudžuka. Daredevil: Back in Black Vol. 5: Supreme. New York: Marvel, 2017.

"Daredevil \#21 'Supreme’ Part 1.” In Daredevil: Back in Black Vol. 5: Supreme. New York: Marvel, 2017.

“Daredevil \#22 ‘Supreme’ Part 2.” In Daredevil: Back in Black Vol. 5: Supreme. New York: Marvel, 2017.

Waid, Mark, Peter Krause, Javier Rodriguez and Chris Samnee. Daredevil Vol. 1: Devil At Bay. New York: Marvel, 2014.

Waid, Mark, Chris Samnee and Javier Rodriguez, Daredevil Vol. 3. New York: Marvel, 2014.

Zdarsky, Chip, Marco Checchetto and Lalit Kumar Sharma. Daredevil by Chip Zdarsky Vol. 1: Know Fear. New York: Marvel, 2019.

\section{Secondary Sources}

Agamben, Giorgio. The State of Exception. Chicago and London: University of Chicago Press, 2005.

Alaniz, José. Death, Disability and the Superhero: The Silver Age and Beyond. Jackson: University Press of Mississippi, 2014.

Alloa, Emmanuel. "Seeing-as, Seeing-in, Seeing-with.” In Image and Imaging in Philosophy, Science, and the Arts. Volume I. Proceedings of the 33rd International Wittgenstein Symposium, edited by Elisabeth Nemeth, Richard Heinrich, Wolfram Pichler and David Wagner, 179-190. Frankfurt: Ontos, 2011.

Asimow, Michael. "When Lawyers Were Heroes.” University of San Francisco Law Review 30, no 4 (1996): 1131-38.

Bainbridge, Jason. "Beyond the Law: What is So 'Super' About Superheroes and Supervillains?” International Journal for the Semiotics of Law 30, no 3 (2017): 367-88. https://doi.org/10.1007/s11196-017-9514-0

" "The Call to Do Justice': Superheroes, Sovereigns and the State During Wartime." International Journal for the Semiotics of Law 28, no 4 (2015): 745-63. https://doi.org/10.1007/s11196-015-9424-y

. " 'I Am New York'-Spider-Man, New York City and the Marvel Universe." In Comics and the City: Urban Space in Print, Picture and Sequence, edited by Jörn Ahrens and Arno Meteling, 163-179. New York: Continuum, 2010.

. "Lawyers, Justice and the State: The Sliding Signifier of Law in Popular Culture." Griffith Law Review 15, no 1 (2006): 153-76. https://doi.org/10.1080/10383441.2006.10854569

. "Spider-Man, The Question and The Meta-Zone: Exception, Objectivism and the Comics of Steve Ditko." Law Text Culture 16, no 1 (2012): 217-242.

. "This is the Authority. This Planet is Under Our Protection'-An Exegesis of Superheroes' Interrogations of Law." Law, Culture and the Humanities 3, no 3 (2007): 455-76. https://doi.org/10.1177\%2F1743872107081431 
Berkowitz, Roger. "From Justice to Justification: An Alternative Genealogy of Positive Law." UC Irvine Law Review 1, no 3 (2011): 611-30.

Berman, Harold. Law and Revolution: The Formation of the Western Legal Tradition. Cambridge, MA: Harvard University Press, 1983.

Brant, Sebastian. The Ship of Fools. Translated by William Gillis. London: Folio Society, 1971.

Briest, Sarah. "The Allegorical X-Men: Emblems, Comics, and the Allegorical Potential of Text/Image Hybrid Genres." ImageTexT 9, no 1 (2017).

Brownie, Barbara and Danny Graydon. The Superhero Costume: Identity and Disguise in Fact and Fiction. London: Bloomsbury, 2016.

Bukatman, Scott. "Secret Identity Politics.” In The Contemporary Comic Book Superhero, edited by Angela Ndalianis, 10925. London: Taylor \& Francis Group, 2008.

Cavallar, Osvaldo, Susanne Degenring and Julius Kirshner. A Grammar of Signs: Bartolo De Sassoferrato's Tract on Insignia and Coats of Arms. Berkeley, CA: Robins Collection Publications, 1994.

Coogan, Peter. Superhero: The Secret Origin of a Genre. Austin, TX: MonkeyBrain Books, 2006.

Cover, Robert M. "Violence and the Word." Yale Law Journal 95 (1986): 1601-29.

Crawley, Karen and Desmond Manderson. "The Confessor: Oprah Winfrey, James Frey and the Logic of Confession." In Envisioning Legality: Law, Culture and Representation, edited by Timothy D. Peters and Karen Crawley, 161-90. London: Routledge, 2018.

Crawley, Karen and Timothy D. Peters. "Introduction: 'Representational Legality'.” In Envisioning Legality: Law, Culture and Representation, edited by Timothy D. Peters and Karen Crawley, 1-17. London: Routledge, 2018.

Curtis, Neal. Sovereignty and Superheroes. Manchester: Manchester University Press, 2016.

- "Superheroes and the Contradiction of Sovereignty." Journal of Graphic Novels and Comics 4, no 2 (2013): $209-22$. https://doi.org/10.1080/21504857.2013.803993

Douzinas, Costas and Lynda Nead, eds. Law and the Image: The Authority of Art and the Aesthetics of Law. Chicago and London: University of Chicago Press, 1999.

Douzinas, Costas. "Prosopon and Antiprosopon: Prolegomena for a Legal Iconology." In Law and Image: The Authority of Art and the Aesthetics of Law, edited by Costas Douzinas and Lynda Nead, 36-67. Chicago: The University of Chicago Press, 1999.

Eisner, Will. Comics \& Sequential Art. N.p.: Poorhouse Press, 1985.

Ferris, Graham and Cleo Lunt. "Devil's Advocate: Representation in Heroic Fiction, Daredevil and the Law." In Graphic Justice: Intersections of Comics and Law, edited by Thomas Giddens, 50-67. Abingdon: Routledge, 2015.

Fort, George F. The Early History and Antiquities of Freemasonry. Philadelphia: Bradley \& Company, 1881.

Giddens, Thomas. “Anderson v Dredd [2137] Mega-City LR 1.” International Journal for the Semiotics of Law 30, no 3 (2017): 389-405. https://doi.org/10.1007/s11196-016-9492-7

Giddens, Thomas, ed. Critical Directions in Comics Studies. Jackson: University Press of Mississippi, 2020.

- Graphic Justice: Intersections of Comics and Law. Abingdon: Routledge, 2015.

Giddens, Thomas. "Lex Comica: On Comics and Legal Theory." In Graphic Justice: Intersections of Comics and Law, edited by Thomas Giddens, 8-15. Abingdon: Routledge, 2015.

- "Natural Law and Vengeance: Jurisprudence on the Streets of Gotham." International Journal for the Semiotics of Law 28, (2015): 765-85. https://doi.org/10.1007/s11196-014-9392-7

_ "Navigating the Looking Glass: Severing the Lawyer's Head in Arkham Asylum." Griffith Law Review 24, no 3 (2015): 395-417. https://doi.org/10.1080/10383441.2015.1119777

. On Comics and Legal Aesthetics: Multimodality and the Haunted Mask of Knowing. Abingdon: Routledge, 2018.

Gómez Romero, Luis and Ian Dahlman, ed. “Justice Framed: Law in Comics and Graphic Novels.” Special Issue of Law Text Culture 16, (2012).

Gómez Romero, Luis and Ian Dahlman. "Introduction - Justice Framed: Law in Comics and Graphic Novels.” Law Text Culture 16, (2012): 3-32.

Goodrich, Peter. "The Foolosophy of Justice and the Enigma of Law." Yale Journal of Law \& the Humanities 24, no 1 (2013): 141-78.

- Legal Emblems and the Art of Law: Obiter Depicta as the Vision of Governance. New York: Cambridge University Press, 2014.

—. "The Mask as Anti-Apparatus: On the Counter-Dispositif of V for Vendetta." In Critical Directions in Comics Studies, edited by Thomas Giddens, 238-62. Jackson: University Press of Mississippi, 2020.

—. "The Theatre of Emblems: On the Optical Apparatus and the Investiture of Persons." Law, Culture and the Humanities 8, (2012): 47-67. https://doi.org/10.1177\%2F1743872110361226

—. "Visiocracy: On the Futures of the Fingerpost." Critical Inquiry 39, no 2 (2013): 498-531. https://doi.org/10.1086/670043

Goodrich, Peter and Valérie Hayaert, eds. Genealogies of Legal Vision. New York: Routledge, 2015. 
Grove, Laurence. Text/Image Mosaics in French Culture: Emblems and Comic Strips. London: Routledge, 2016.

Harrison, Alice. "The Law Relating to Informer Privilege." Galway Student Law Review 4, (2010): 41-55.

Hayaert, Valérie. "Emblems." In The Oxford Handbook of Law and Humanities, edited by Simon Sterne, 757-78. Oxford: Oxford University Press, 2019.

- Mens Emblematica et Humanisme Juridique: Le cas du Pegma Cum Narrationibus Philosophicus de Pierre Coustau. Geneva, Switzerland: Droz, 2008.

Henderson, Stephen E. "Daredevil: Legal (and Moral) Vigilante.” Ohio State Journal of Criminal Law 15, no 1 (2017): 13382.

Holmes, Oliver Wendall. "The Path of the Law." Harvard Law Review 10, no 8 (1897): 457-78.

“The Informer Privilege: What's in a Name?” The Journal of Criminal Law and Criminology 64, no 1 (1973): 56-66. https://dx.doi.org/10.2307/1142656

Ingersoll, Bob. The Law Is a Ass: Volume One: All Rise. Pulp Hero Press, 2019.

Jay, Martin. "Must Justice Be Blind? The Challenges of Images to the Law." In Law and the Image: The Authority of Art and the Aesthetics of Law, edited by Costas Douzinas and Lynda Nead, 19-35. Chicago: The University of Chicago Press, 1999.

Kamir, Orit. “Anatomy of Hollywood's Hero-Lawyer: A Law and Film Study of the Western Motifs, Honor-Based Values and Gender Politics Underlying Anatomy of a Murder." In Studies in Law, Politics and Society: Volume 35, edited by Austin Sarat, 67-105. Bingley: Emerald Group Publishing Limited, 2005.

"Michael Clayton: Hollywood's Contemporary Hero-Lawyer: Beyond 'Outsider Within' and 'Insider Without'." Suffolk University Law Review 42, no 4 (2009): 829-48.

Kantorowicz, Ernst. The King's Two Bodies: A Study in Mediaeval Political Theology. Princeton, NJ: Princeton University Press, 1997.

Karsai, Liza I. "You Can’t Give My Name: Rethinking Witness Anonymity in Light of the United States and British Experience." Tennessee Law Review 79, no 1 (2011): 29-94.

Lusty, David. "Anonymous Accusers: An Historical \& Comparative Analysis of Secret Witnesses in Criminal Trials." Sydney Law Review 24, (2002): 361-426.

Maitland, Frederic William. "The Corporation Sole.” In State, Trust and Corporation, edited by David Runciman and Magnus Ryan, 9-31. Cambridge: Cambridge University Press, 2003.

- "The Crown as Corporation." In State, Trust and Corporation, edited by David Runciman and Magnus Ryan, 32-51. Cambridge: Cambridge University Press, 2003.

Manderson, Desmond. Danse Macabre: Temporalities of Law in the Visual Arts. Cambridge: Cambridge University Press, 2019.

Manderson, Desmond, ed. Law and the Visual: Representations, Technologies, Critique. Toronto: University of Toronto Press, 2018.

Manderson, Desmond. "Introduction: Imaginal Law." In Law and the Visual: Representations, Technologies and Critique, edited by Desmond Manderson, 3-20. Toronto: Toronto University Press, 2018.

- "The Metastases of Myth: Legal Images as Transitional Phenomena." Law and Critique 26, (2015): 207-23. https://doi.org/10.1007/s10978-014-9149-1

. "Trench, Trail, Screen: Scenes from the Scopic Regime of Sovereignty." In Envisioning Legality: Law, Culture and Representation, edited by Timothy D. Peters and Karen Crawley, 140-60. London: Routledge, 2018.

—. "Trust Us Justice: '24', Popular Culture and the Law." In Imagining Legality: Where Law Meets Popular Culture, edited by Austin Sarat, 22-52. Tuscaloosa: The University of Alabama Press, 2011.

Mares, Henry. "Balancing Public Interest and a Fair Trial in Police Informer Privilege: A Critical Australian Perspective." The International Journal of Evidence \& Proof 6, no 2 (2002): 94-124. https://dx.doi.org/10.1177/136571270200600202.

Marin, Louis. Portrait of the King. Hampshire: Macmillan Press, 1988.

Mitchell, Dale. "Paradoxes and Patriarchy: A Legal Reading of She-Hulk." Griffith Law Review 24, no 3 (2015): $446-81$. https://doi.org/10.1080/10383441.2015.1087367

Mondzain, Marie-Jose. Image, Icon, Economy: The Byzantine Origins of the Contemporary Imaginary. Stanford, CA: Stanford University Press, 2004.

Parker, James E. K. “Gavel.” In International Law's Objects, edited by Jessie Hohmann and Daniel Joyce, 214-224. Oxford: Oxford University Press, 2018.

Peters, Timothy D. and Karen Crawley, eds. Envisioning Legality: Law, Culture and Representation. London: Routledge, 2018.

Peters, Timothy D. "Beyond the Limits of the Law: A Christological Reading of Christopher Nolan's The Dark Knight." Griffith Law Review 24, no 3 (2015): 418-45. https://doi.org/10.1080/10383441.2015.1096985

_. " 'Seeing' Justice Done: Envisioning Legality in Christopher Nolan's The Dark Knight Trilogy.” In Envisioning Legality: Law, Culture and Representation, edited by Timothy D. Peters and Karen Crawley, 68-95. London: Routledge, 2018. 
"Theological 'Seeing' of Law: Daredevil, Christian Iconography, and Legal Aesthetics." In Critical Directions in Comics Studies, edited by Thomas Giddens, 77-102. Jackson, MS: University Press of Mississippi, 2020.

Phillips, Nickie D. and Staci Strobl. "Cultural Criminology and Kryptonite: Apocalyptic and Retributive Constructions of Crime and Justice in Comic Books.” Crime, Media, Culture 2, no 3 (2006): 304-31. https://doi.org/10.1177\%2F1741659006069573

Comic Book Crime: Truth, Justice and the American Way. New York: New York University Press, 2013.

Pitkethly, Clare. "The Pursuit of Identity in the Face of Paradox: Indeterminacy, Structure and Repetition in Superman, Batman and Wonder Woman." Journal of Graphic Novels and Comics 3, no 2 (2012): 215-21. https://doi.org/10.1080/21504857.2011.599847

Resnik, Judith and Dennis E. Curtis. Representing Justice: Invention, Controversy and Rights in City-States and Democratic Courtrooms. New Haven: Yale University Press, 2011.

Rosen, Louis Michael. “The Lawyer as Superhero: How Marvel Comics’ Daredevil Depicts the American Court System and Legal Practice.” Capital University Law Review 47, (2019): 379-433.

Saltzburg, Stephen A. "Informant Privilege." Criminal Justice 30, no 2 (2015): 60-63.

Santner, Eric. The Royal Remains: The People's Two Bodies and the Endgames of Sovereignty. Chicago: The University of Chicago Press, 2011.

Sarat, Austin. "Imagining the Law of the Father: Loss, Dread and Mourning in The Sweet Hereafter." Law \& Society Review 34, no 1 (2000): 3-46.

Sharp, Cassandra. " 'Fear' and 'Hope' in Graphic Fiction: The Schismatic Role of Law in Australian Dystopian Comic." International Journal for the Semiotics of Law 30, (2017): 407-26.

—. Cassandra. " 'Riddle Me This...?' Would the World Need Superheroes if the Law Could Actually Deliver 'Justice'?” Law Text Culture 16, no 1 (2012): 353-78.

Sherwin, Richard. "Introduction." In Law, Culture and Visual Studies, edited by Anne Wagner and Richard Sherwin, xxxiiixli. New York: Springer, 2014.

. Visualising Law in the Age of the Digital Baroque: Arabesques and Entanglements. London: Routledge, 2011.

. "What Authorizes the Image? The Visual Economy of Post-Secular Jurisprudence." In Law and the Visual:

Transitions and Transformations, edited by Desmond Manderson, 330-54. Toronto: University of Toronto Press, 2018.

Sleep, Lyndal and Kieran Tranter. "The Visiocracy of the Social Security Mobile App in Australia." International Journal for the Semiotics of Law 30, (2017): 495-514. https://doi.org/10.1007/s11196-016-9498-1

Spanakos, Anthony Peter. "Hell's Kitchen's Prolonged Crisis and Would-Be Sovereigns: Daredevil, Hobbes, and Schmitt." Political Science \& Politics 47, no 1 (2014): 94-97. https://doi.org/10.1017/S1049096513001698

Tamanaha, Brian. Law as a Means to an End: Threat to the Rule of Law. Cambridge: Cambridge University Press, 2006.

Taslitz, Andrew. "Daredevil and the Death Penalty." Ohio State Journal of Criminal Law 1, (2004): 699-717.

Tranter, Kieran. "Law, the Digital and Time: The Legal Emblems of Doctor Who." International Journal for the Semiotics of Law 30, (2017): 515-32.

Vollum, Scott and Cary Adkinson. "The Portrayal of Crime and Justice in the Comic Book Superhero Mythos." Journal of Criminal Justice and Popular Culture 10, no 2 (2003): 96-108.

Wagner, Anne and Richard Sherwin, eds. Law, Culture and Visual Studies. New York: Springer, 2014.

Weltzien, Friedrich. "Masque-ulinities: Changing Dress as a Display of Masculinity in the Superhero Genre." Fashion Theory 9, no 2 (2005): 229-50. https://doi.org/10.2752/136270405778051374

Young, Paul. Frank Miller's Daredevil and the Ends of Heroism. New Brunswick: Rutgers University Press, 2016.

\section{Magazines, Blogs, Websites}

Daily, James. "Costumes and the Confrontation Clause.” Law and the Multiverse (blog), 3 January, 2011, https://lawandthemultiverse.com/2011/01/03/costumes-and-the-confrontation-clause/

Davidson, Ryan. "Superheros and Alter-Egos." Law and the Multiverse (blog), 1 December, 2010, https://lawandthemultiverse.com/2010/12/01/superheros-and-alter-egos/

Ingersoll, Bob. "The Law Is a Ass \#442: Daredevil Shouldn’t Give a Testimony-Al.” ComicMix (blog), 10 June, 2019 , https://www.comicmix.com/2019/06/10/the-law-is-a-ass-442-daredevil-shouldnt-give-a-testimony-al/

. "The Law Is a Ass \#443: Daredevil Has to Prove He’s the Devil You Know.” ComicMix (blog), 17 June, 2019, https://www.comicmix.com/2019/06/17/the-law-is-a-ass-443-daredevil-has-to-prove-hes-the-devil-you-know/

. "The Law Is a Ass \#444: So, Is Daredevil Appealing?” ComicMix (blog), 24 June, 2019,

https://www.comicmix.com/2019/06/24/the-law-is-a-ass-444-so-is-daredevil-appealing/

. "The Law Is a Ass \#445: The Justices Tell Daredevil SCOTUS Hell.” ComicMix (blog), 1 July, 2019,

https://www.comicmix.com/2019/07/01/the-law-is-a-ass-445-the-justices-tell-daredevil-scotus-hell/ 